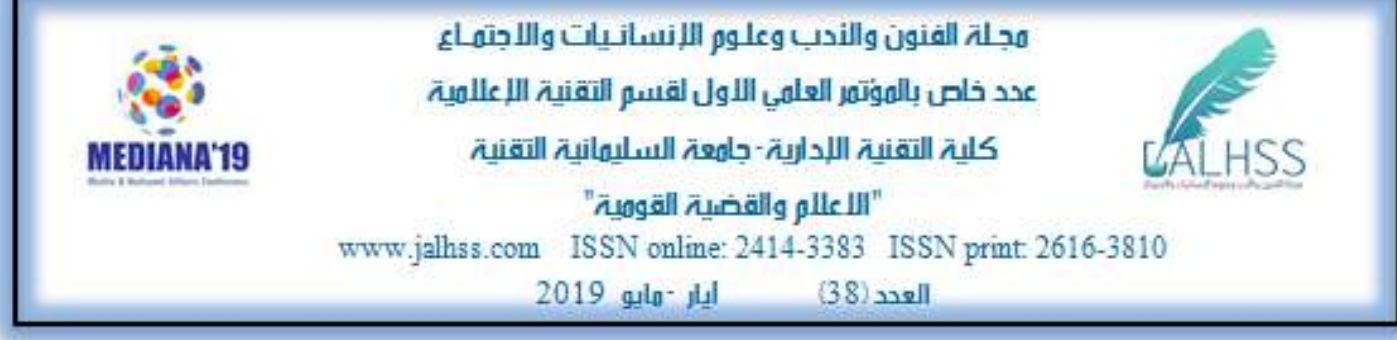

\title{
دور مواقع التواصل الاجتماعي في إعطاء المعلومات نحو تشكيل حكومة إقليم كوردستان إعطاء المعان
}

(دراسة ميدانية على عينة من موظفي جامعة السليمانية التقنية)
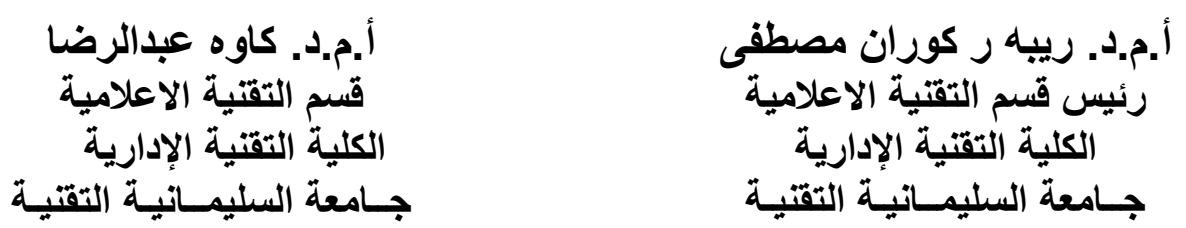

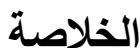

يهذف هذا البحث الدور الذي تقوم بها مواقع التواصل الاجتماعي في إعطاء المعلومات نحو تشكيل حكومة إقليم كوردستان لاى موظفي جامعة السليمانية التقنية، هذا البحث من نوع البحوث الوصفي الذي يعتمد على

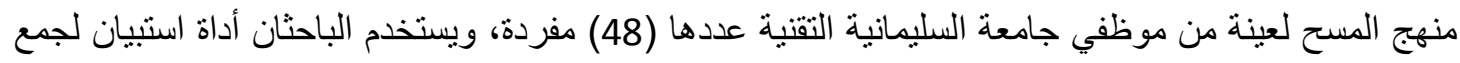
البيانات و المعلومات تتعلق بتساؤلات وفروض البحث، ويوصلوا الباحثان إلى عدة نتائج من أهمها: توجد علاقة ارتباطية دالة إحصائية بين مدى استخدام مواقع التواصل الاجتماعي في إعطاء المعلومات نحو تشكيل حكومة إنى إقليم كوردستان لاى موظفي الجامعة، وتوجد فروق ذو دلالة إحصائية بين المبحوثين في إعطاء المعلومات نحو إعو تشكيل حكومة إقليم كوردستان حسب المتغير ات الديمو غر افية. 


\title{
The Role of Social Networking Sites in Giving Information towards the Formation of the Kurdistan Regional Government
}

(A field study on a sample of employees of the University of Sulaymaniyah Technical)

\begin{abstract}
The purpose of this research is the role played by the social networking sites in giving information about the formation of the Kurdistan Regional Government in the staff of Sulaimania Technical University. This research is descriptive research based on the survey methodology of a sample of 48 employees of Sulaymania Technical University. A questionnaire is used to collect data and information related to the questions and research hypotheses. The researchers reach several results, the most important of which are: There is a statistical correlation between the extent of use of social networking sites in providing information about the formation of the Kurdistan Regional Government in the university staff. Statisticians among the respondents in giving information about the formation of the Kurdistan Regional Government according to demographic variables.
\end{abstract}


مجِ لات الفنون والندب وعاوم اللإنسانيات واللاجتهاع

عدد خام بالهونتمر العلمي اللاول لقسم التقنية اللاعلامية

كلية التقنية الليدازية-جامعت السليمانية التقنية

"

www.jalhss.com ISSN online: $2414-3383$ ISSN print $2616-3810$

2019 العدي

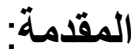

تعد شبكات التواصل الاجتماعي من أهم تطبيقات الإنترنت في السنوات الأخيرة، فقد خلقت مجتمعات

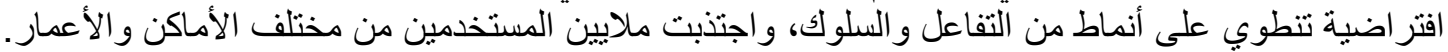

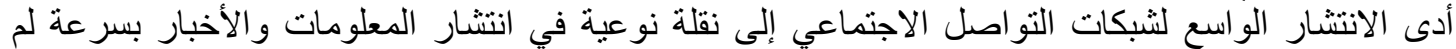

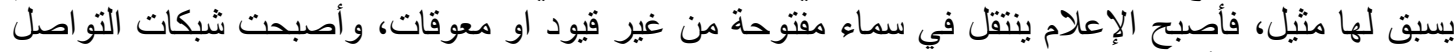

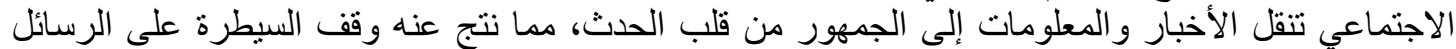

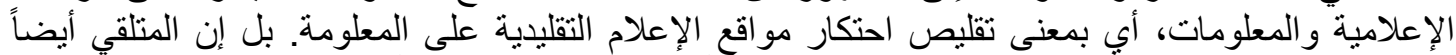

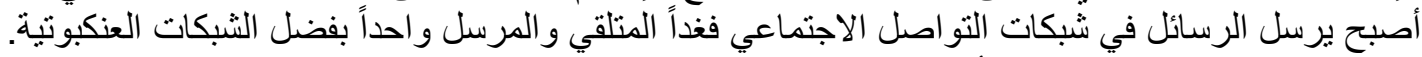

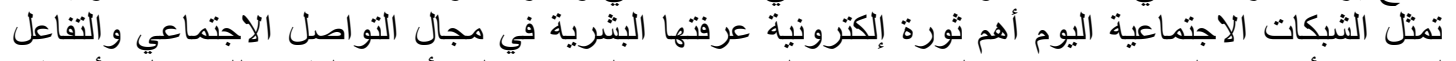

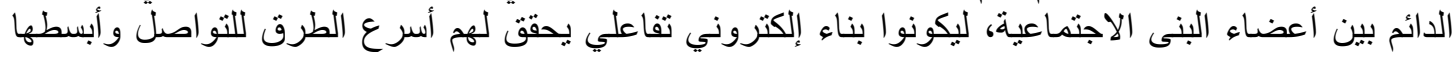

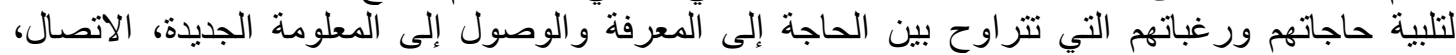

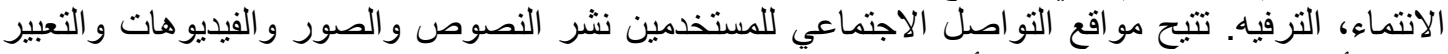

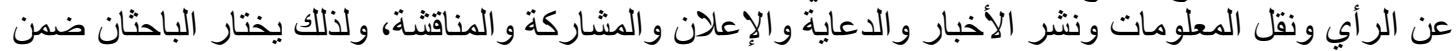

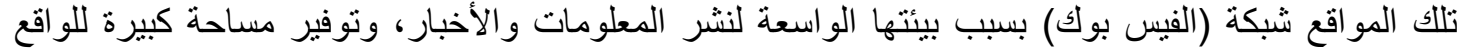
الافتر اضي، لكي تهنم وتتابع وتناقش وتعتمد موظفي الجامعة قضية تنكيل حكومة إقليم كوردستان-العراق.

\section{المطلب الأول: الإطار المنهجي للبحث}

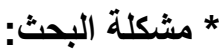

تتمثل مشكلة البحث في طرح التشاؤل التهائلئيسي التالي: ما طبيعة الدور التي تقوم بها مواقع التواصل

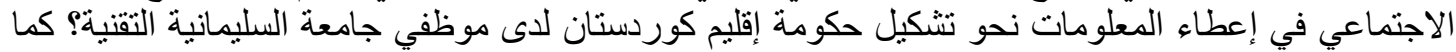

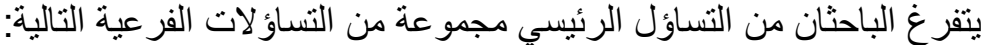

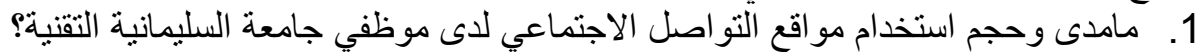

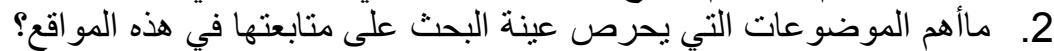

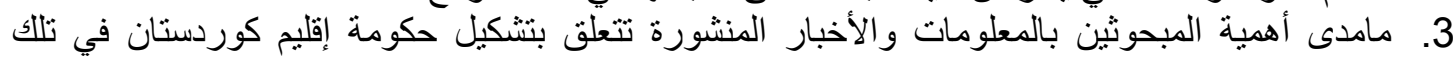

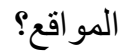
4. مأ طبيعة مواقف موظفي الجامعة في إعطاء معلومات عن تشكيل حكومة إقليم كوردستان لاى مواقع التو اصل الاجتماعي. * أهمية البحث: 1. بعني ببحث آراء موظفي الجامعة في كوردستان/العراق نحو تشكيل حكومة إقليم كوردستان، من خلال إستخدامهم لمو اقع التو اصل الاجتماعي. 2. إتاحة الفرصة للمبحوثين لكي تكتسب معلومات وأخبار عن تشكيل حكومة إقليم كوردستان عبر تلك

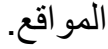
* أهداف البحث:

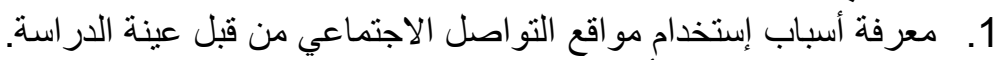

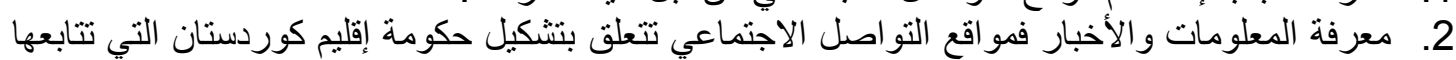
موظفي جامعة السليمانية التقنية. 


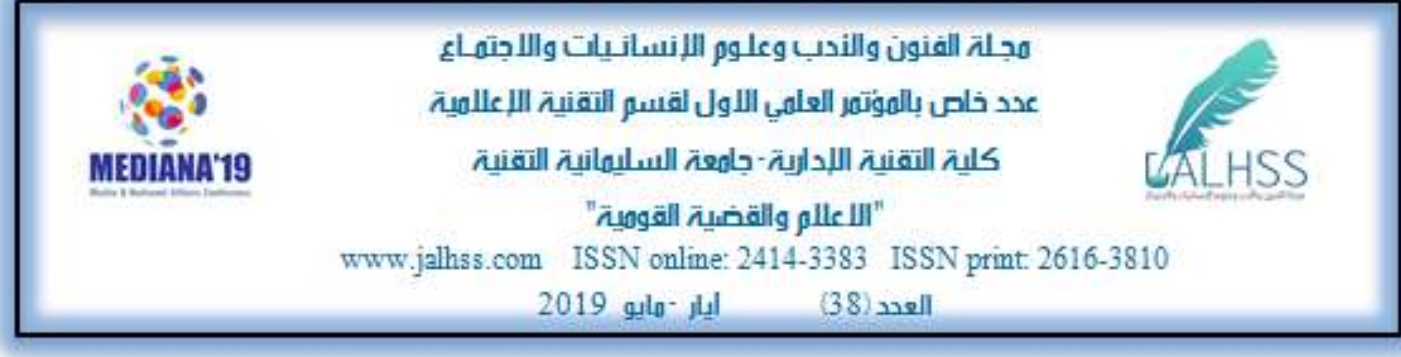

3. معرفة درجة ثقة المبحوثين بالمعلومات التي تحصل عليها في مواقع التواصل الاجتماعي نحو تشكيل حكومة اقليم كوردستان. 4. معرفة أهم الموضورة عات التي أثنارتها مو اقع التو اصل الاجتماعي نحو تشكبل حكومة اقليم كوردستان لاى

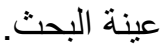

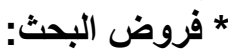
1. توجد علاقة ارتباطية دالة إحصائية بين مدى استخدام مو اقع التواصل الاجتماعي في إعطاء المعلومات

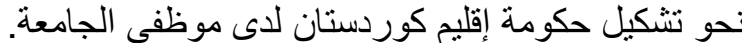
2. توجد فروق ذو دلالة إحصائية بين المبحوثين في إعطاء المعلومات نحو تشكيل حكومة إقليم كوردستان حسب المتغير ات الديمو غر افية.

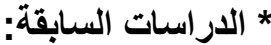
1. دراسة ماطر عبدالله حمدي 2018، (اعتماد الثباب الجامعي على مواقع التواصل الاجتماعي في التزود

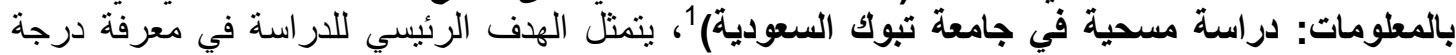

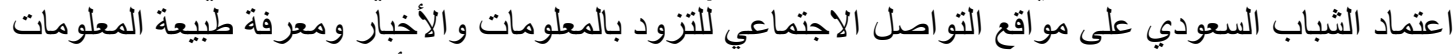

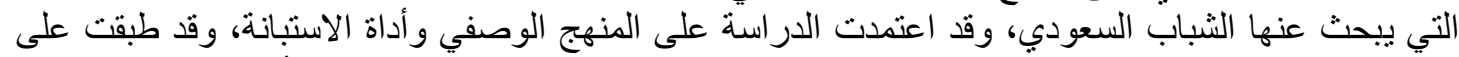

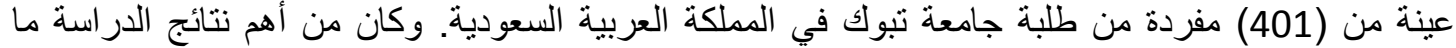

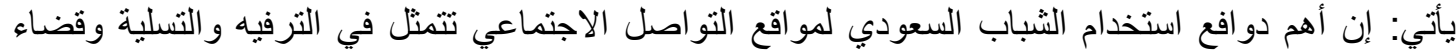

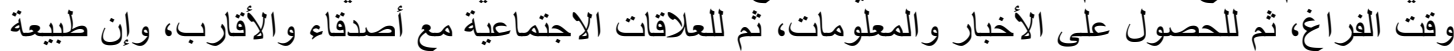

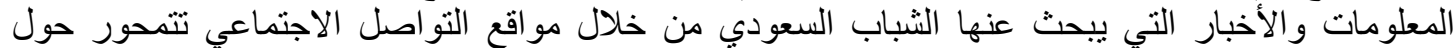

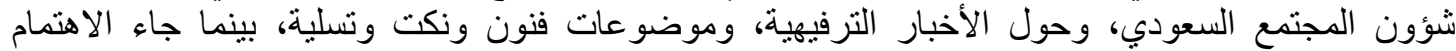

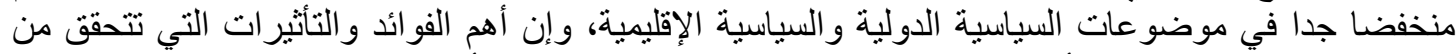

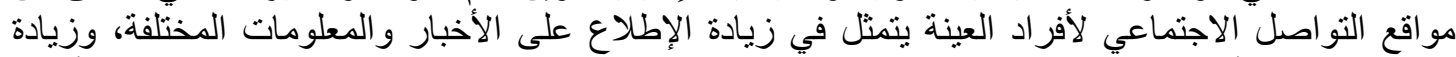

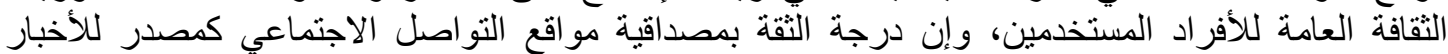
جاءت منوسطة.

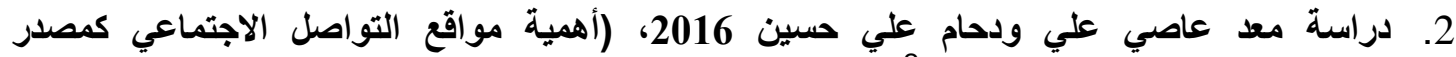

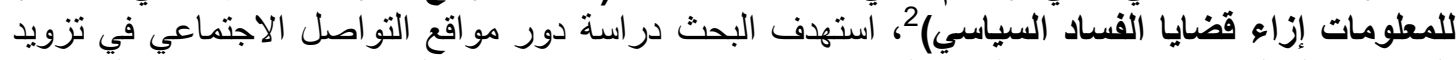

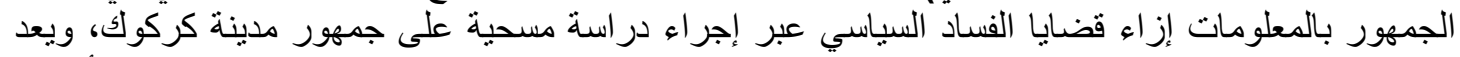

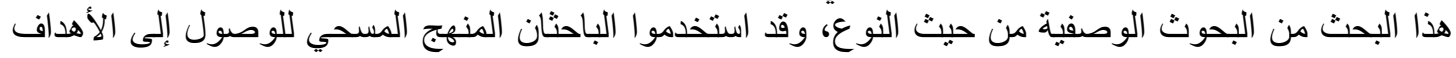
التي يسعى الباحث إلى تحقيقها، وقد وزع الباحثان استبانة بين عينة عشو ائية قوامها (352) مفردة من جمهور

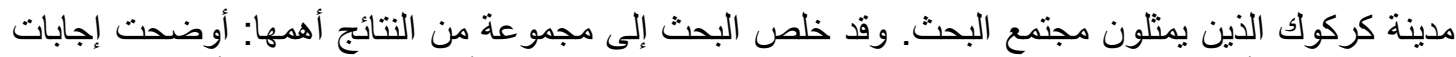

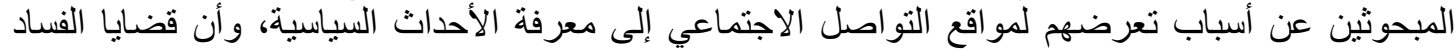

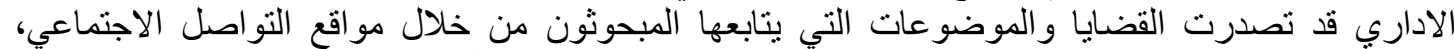

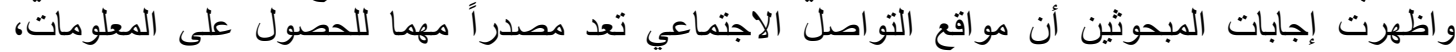

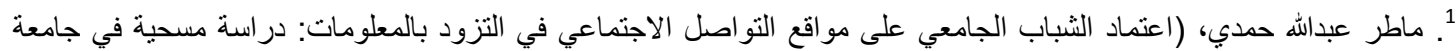

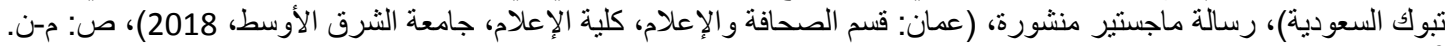

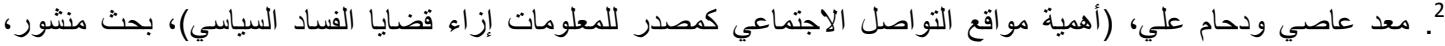
(ديالى: مجلة كلية القانون للعلوم القانونية والسياسية، كلية القانون، جامعة ديالى، 2016)، صاءل: 742-744. 


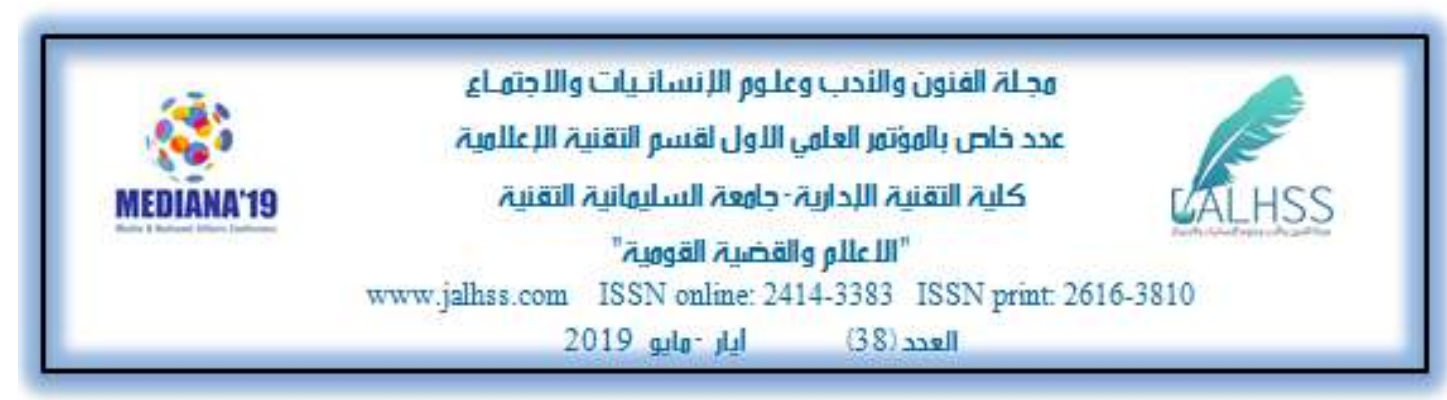

وأوضحت إجابات المبحوثين إلى أن مواقع التو اصل الاجتماعي تسهم بدرجة كبيرة في تزويدهم بالمعلومات إزاء قضايا الفساد.

3. دراسة شرحبيل غالب حميد 2015، (اعتماد طلبة الجامعات الأردنية على شبكات التواصل الاجتماعي

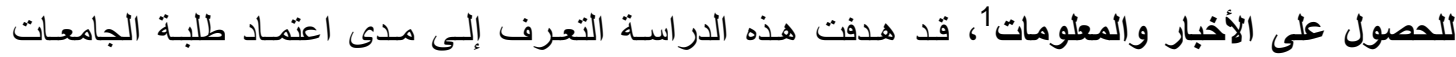

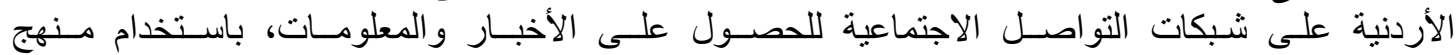

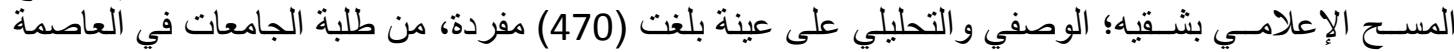

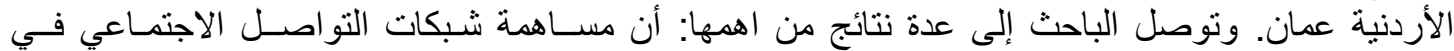

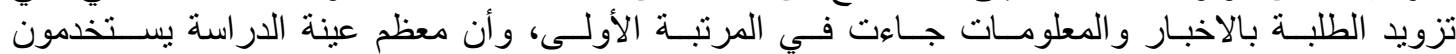

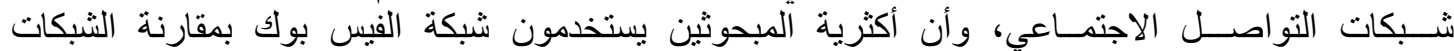

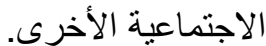

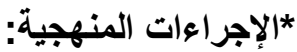

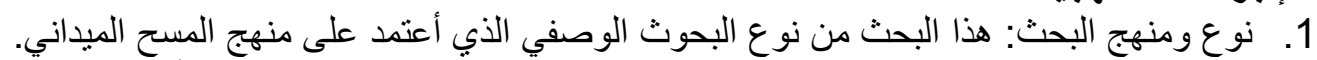

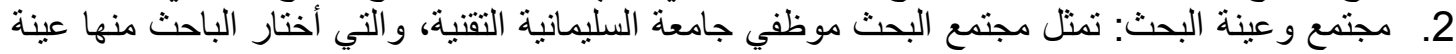

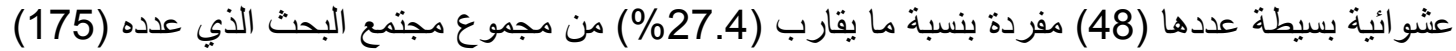

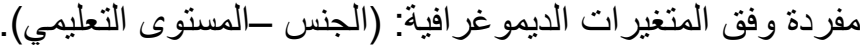
3. أداة البحث: استخدم الباحث استمارة استبيان من أجل الوصول إلى نتائج علمية دقيقة تتعلق بتساؤلات

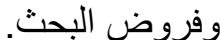

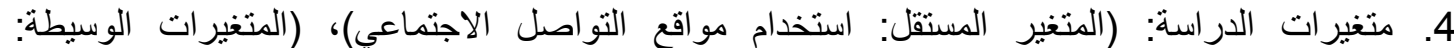

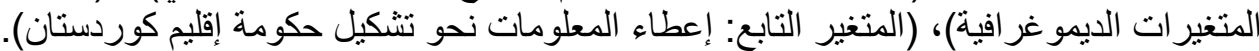

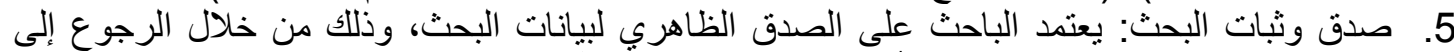

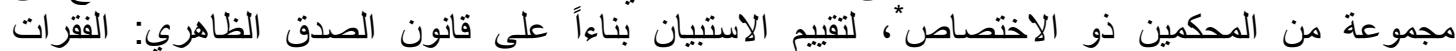

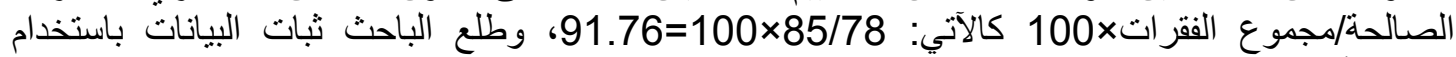

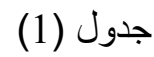
معامل (ألفا كرونباخ) حسب الجدول التالي:

\begin{tabular}{|c|c|c|}
\hline قياس الثبات & عدد الفقر ات & الفقرة \\
\hline 0.816 & 5 & ستخدام \\
\hline
\end{tabular}

تشير نتائج جدول (1) إلى أن قيمة معامل ألفا كرونباخ كانت مرتفعة للأسئلة الترتيبية حيث (0.816) بالنسبة لقياس ثبات استمارة الاستنيان.

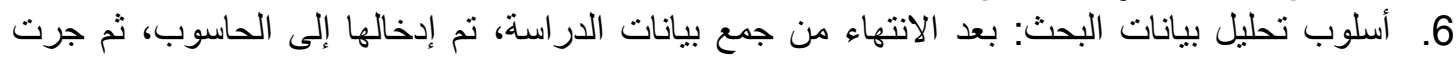

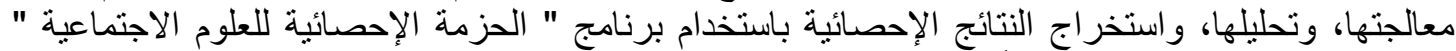

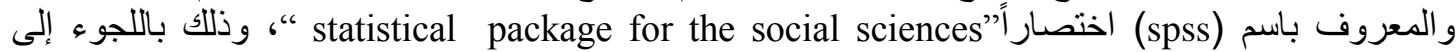

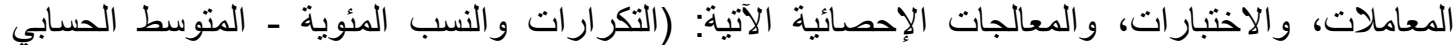
والانحر اف المعياري - المستوى المعنوية ـمعامل ارتباط بيرسون (Pearson Correlation Coefficient)

1. شرحبيل غالب حميد، (اعتماد طلبة الجامعات الأردنية على شبكات التواصل الاجتماعي للحصول على الأخبار والمعلومات)، رسالة ماجستير منشورة، (عمان: كلية الإعلام، جامعة الثرق الأوسط، 2015)، ص: ي-كلكل. 


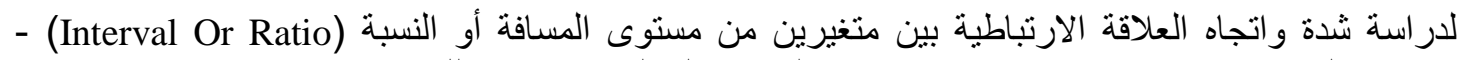

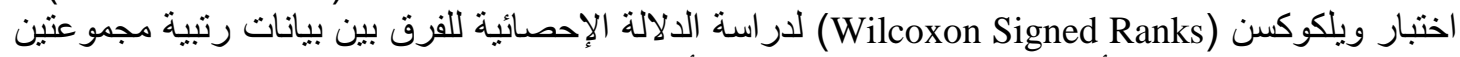
مستقلين من المبحوثين في أحد المتغير ات من نوع المن المسافة أو النسبة (Interval Or Ratio).

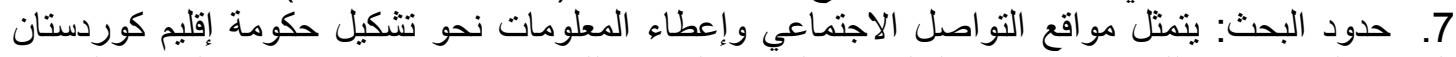
الحدود الموضوعي للبحث، محافظة السليمانية الحدود المكاني للبحث، شهر نيسان 2019 الحدود الزماني

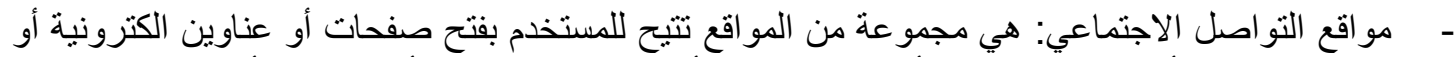

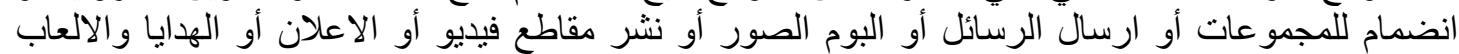

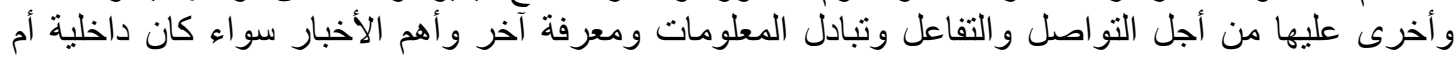
اقليمية أم دولية.

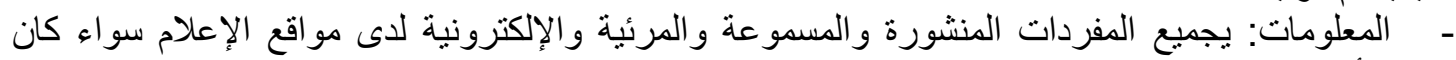
تقليدية أو حديثة.

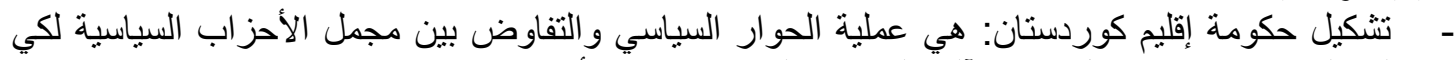

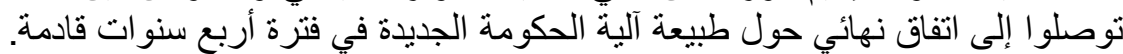

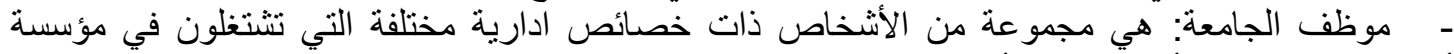

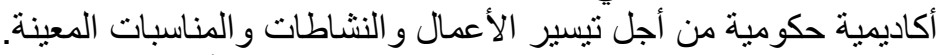

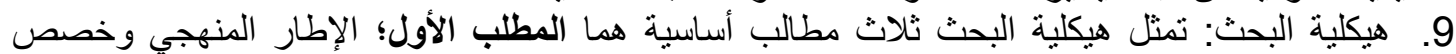

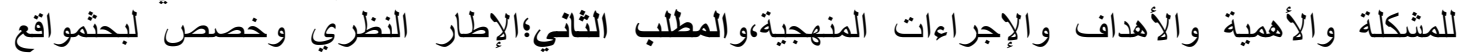

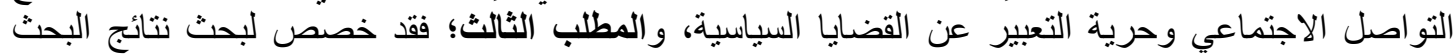

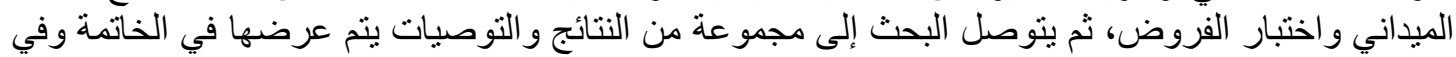

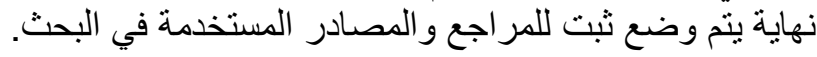

\section{المطلب الثاني: الإطار النظري للبحث}

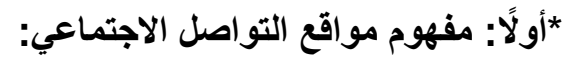

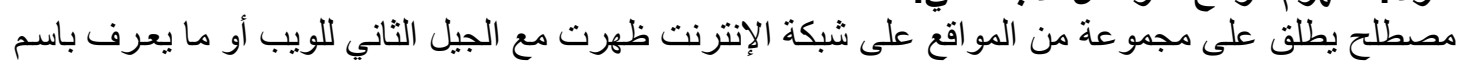

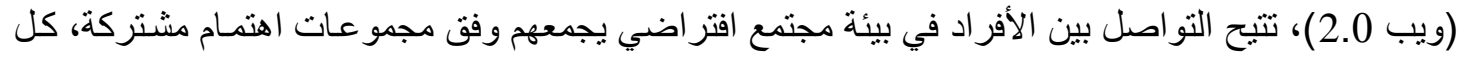

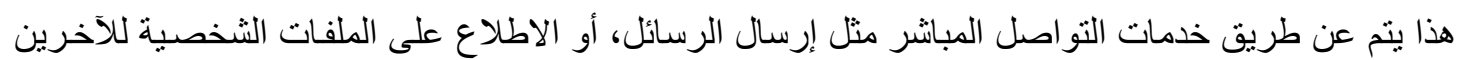

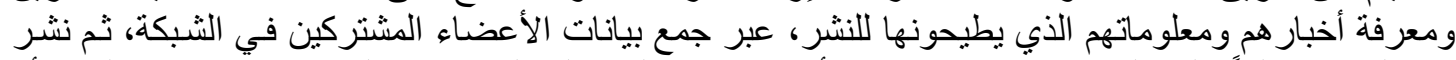

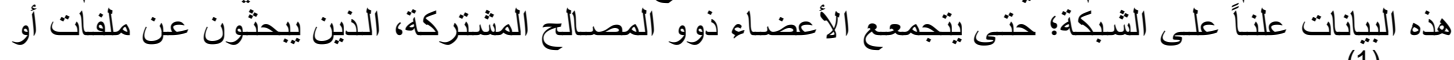

(1) Hitwise and Experian. (Social Networking), 2007, [Online]. Available at: <http://www. Bergenmediaby.no/admin/ressurser/QCetFnO\$_11_Social_Networking_Report_2008.pdf $>$.access to the website on 1-4-2019. 
مجِلة الفنون والندب وعاوم اللإنسانيات واللاجِقهاع

عدد خام بالهونتمر العلمي اللاول لقسم التقنية اللاعلامية

كلية التقنية اللدازية -جاهعت السليمانية التقنية

"

www.jalhss.com ISSN online: $2414-3383$ ISSN print $2616-3810$

2019 العدايل

*ثانيًا: نشأة مواقع التواصل الاجتماعي:

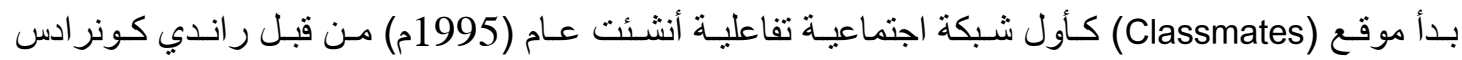

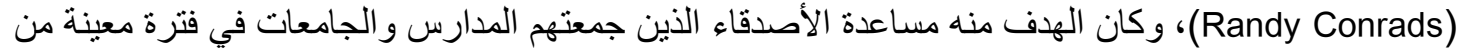

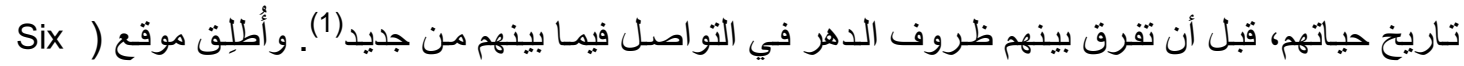

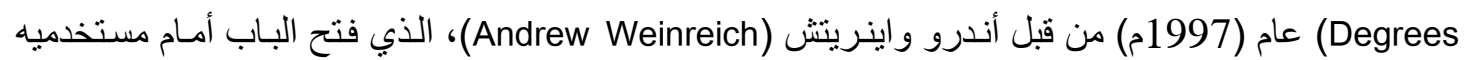

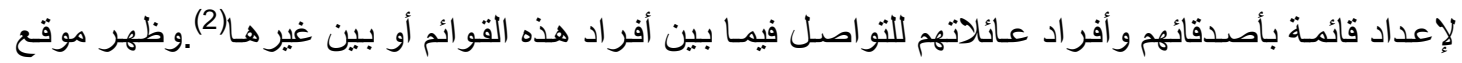

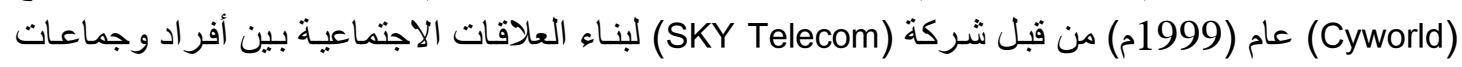

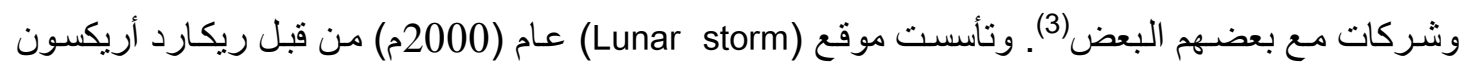

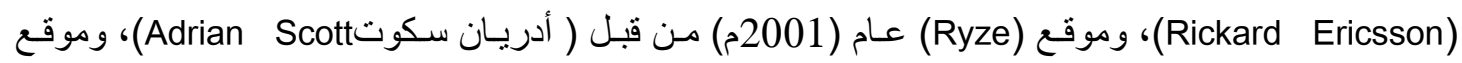
عام (2002م) من قبل جوناثان أبر امس (Friendster)

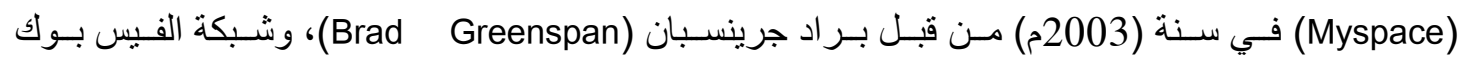
(Facebook) (2006م) من قبل جاك دورسي (Jack Dorsey) الر ائدين في مجال تكوين الصداقة وبناء العلاقات الاجتماعية

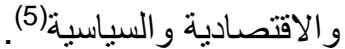

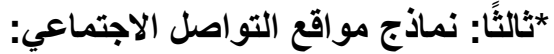

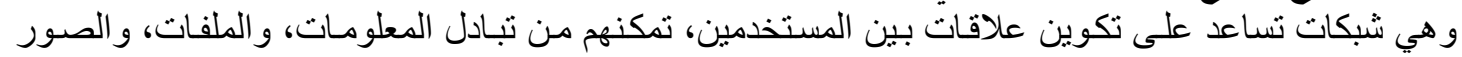

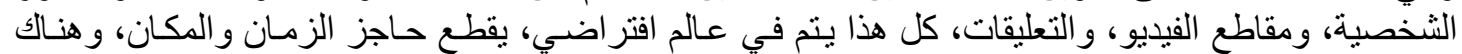

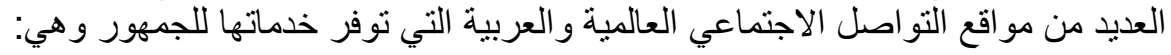

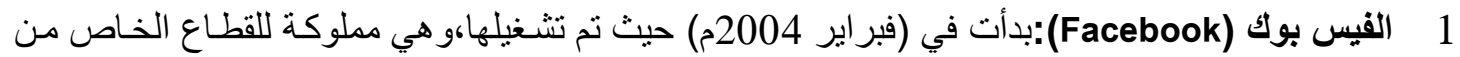
قبل شركة بوك، وصل عدد مستخدميه في (يناير 2012م) اكثر من(845)مليون مستخدم، منهم (483) مليون

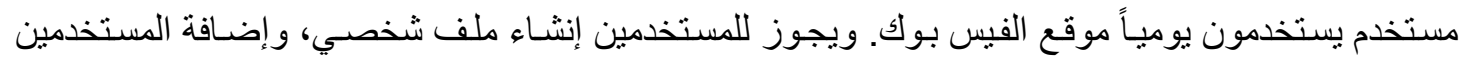

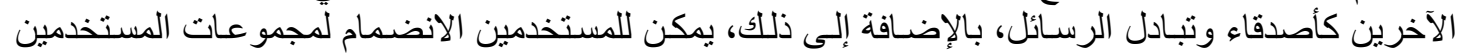

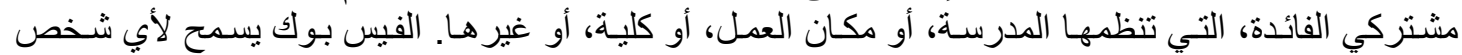

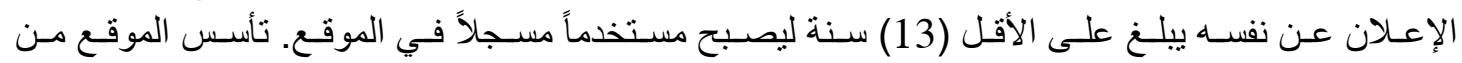

(1) موقع شبكة الأخبار التقنية العربية، (الثبكات الاجتماعية على الإنترنت)، (http://www.tech-arabia.com/?p= 663)،

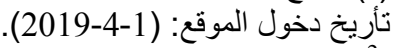
(2) ليلى احمد جرار، (الفيس بوك والثباب العربي)، (عمان: مكتبة الفلاح للنشر والتوزيع، الطبعة الأولى، 2012)، ص38. (2012). $\left(^{3}\right.$ ) www.en.org/ (Cyworld), access to the website on2-4-2019.

$\left({ }^{4}\right)$ www.(Social_networking_service).Org. access to the website on2-4-2019.

( ${ }^{5}$ ) Cindy Royal.(User-Generated Content: How Social Networking Translates to Social Capital), 2008, Association for Education in Journalism and Mass Communication Annual Convention, pdf online, available at:<http://www.allacademic.com/meta/p271193_index.html> access to the website on2-42019. 


\section{هجلة الفنون والندب وعلوم اللإنسانيات واللاجتهـاع \\ عدد خام بالهوتمر العلهي اللاول لقسم التقنية اللـاعلامية كلية التقنية اللدارية -جاهعة السليمانية التقنية}

MEDIAัNA'19

"

www.jalhss.com ISSN online: $2414-3383$ ISSN print $2616-3810$

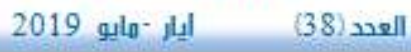

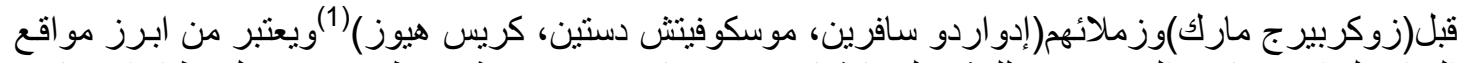

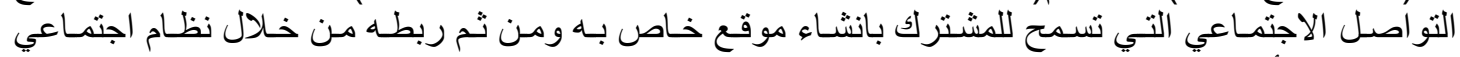

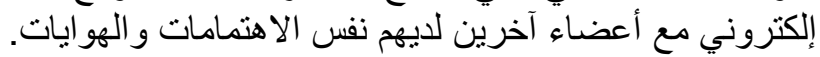

2 (Twitter(التويترئت في (مارس 2006م)، ولديها (190) مليون مستخدم، هي أفضل وسيلة لاكتشاف ما هو جديد في العالم الذي نعيش فيه على شبكة المعلومات. توبتر عبارة عن شبكة المعلومات في الوقت الحقيقي

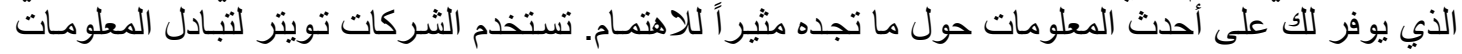

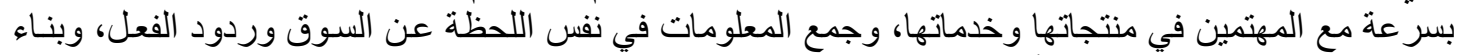

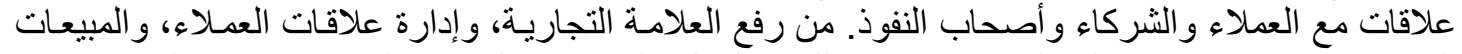

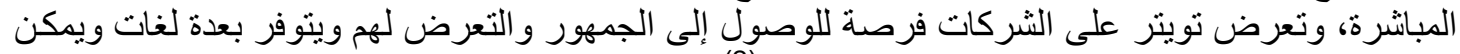

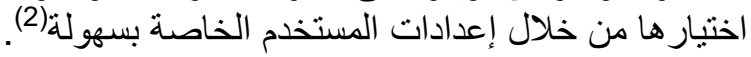

3 برفع ومشاهدة ومشاركة مقاطع الفيديو بشكل مجاني. تأسس في (14 فبر اير سنة 2005) بو اسطة ثلاث موظفين

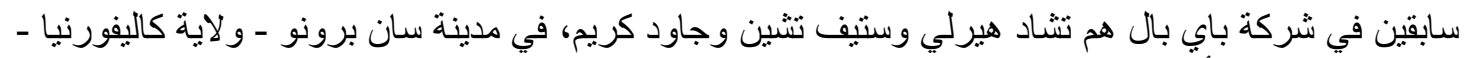

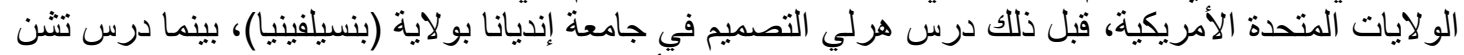

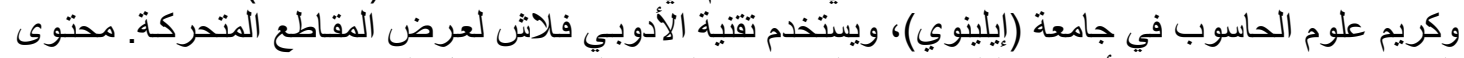

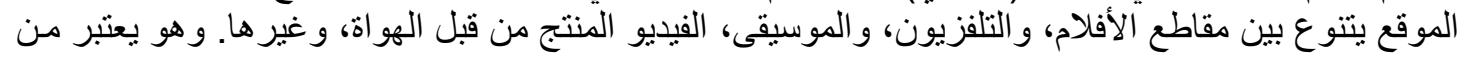

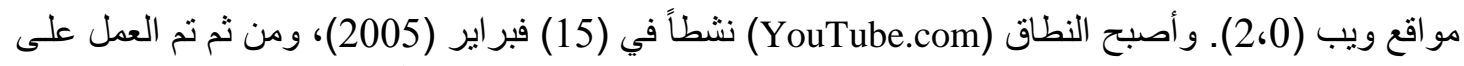
تصميم الموقع لبضع أثهر ـ أفتتح الموقع كتجربة في مايو (2005)، و افتتح رسمياً بعد ستة أثـهر، كمـا أن أول

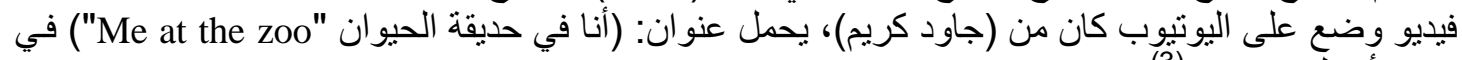
(23) أبريل (2005)

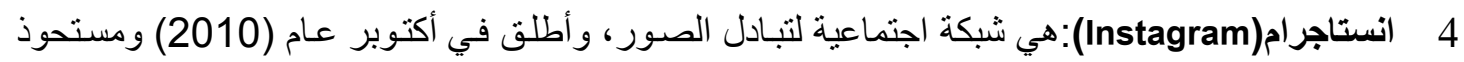

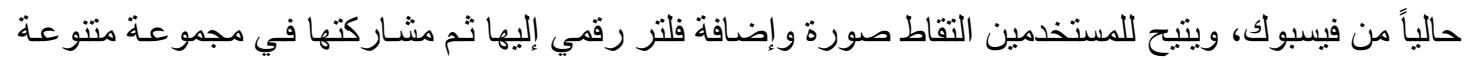

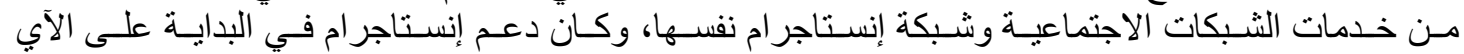

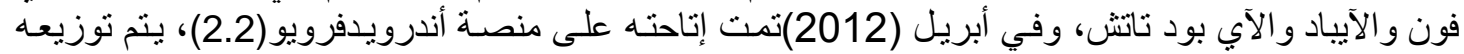

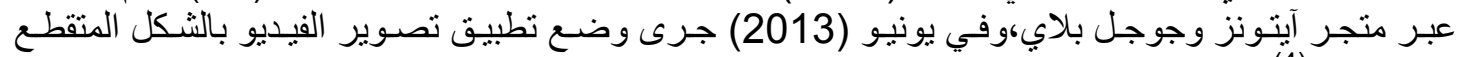

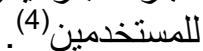

5

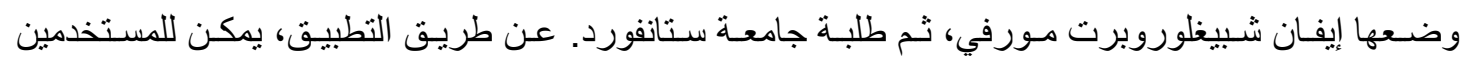

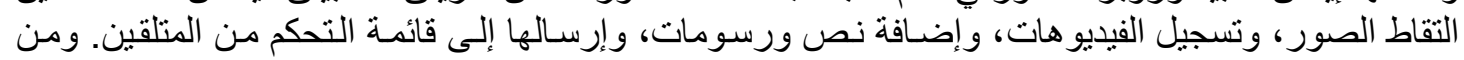

( ${ }^{1}$ Facebook.html online, available at: <http://en.org/wiki/Facebook>.access to the website on3-42019.

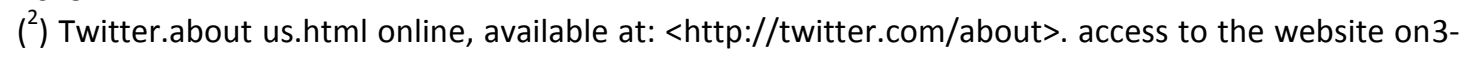
4-2019.

(3) موقع ويكيبيديا، (يوتيوب)، (http://ar.wikipedia.org/wiki)، تاريخ دخول الموقع (4-4-4).

(4) موقع ويكيبيديا، (انستاجر ام)، (http://ar.wikipedia.org/wiki)، تاريخ دخول الموقع (4-4-4). 


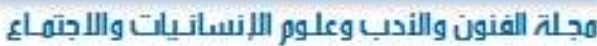

عدد خلم بالهوتمر العلمي اللاول لقسر التقنية اللاعلامية

MEDIAกล'19 كلية التقنية اللدازية -جامعت السليمانية التقنية

"

www.jalhss.com ISSN online: $2414-3383$ ISSN print $2616-3810$

2019 العيد

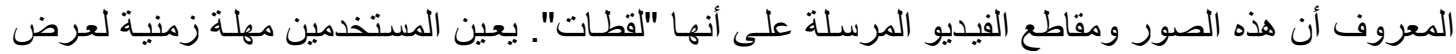

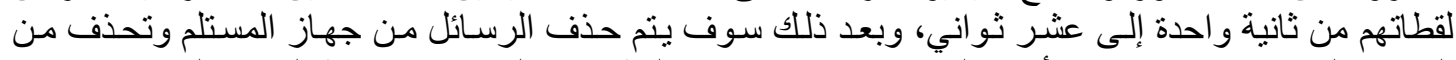

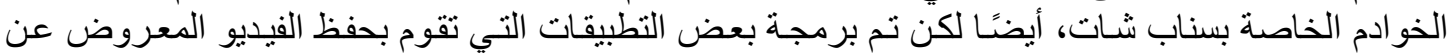

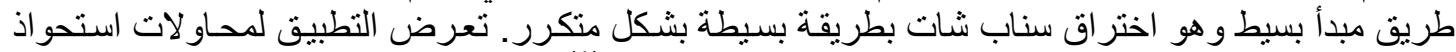

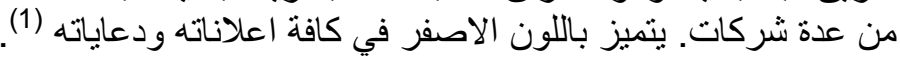

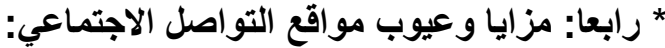

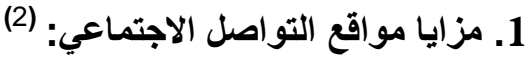

• تو اصل أكبر شريحة من الأفر اد لتبادل المعارف و التفاعل في الموضو عات ذات الاهتمامات المشتركة.

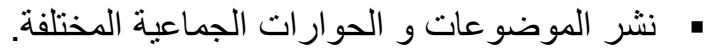

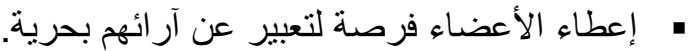

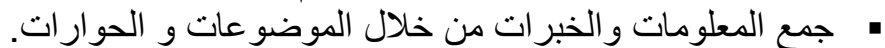

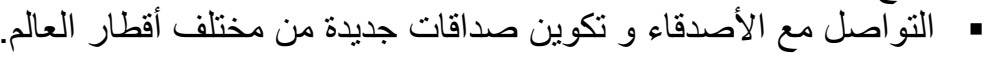

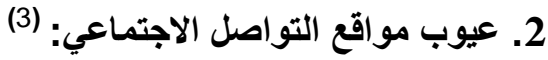

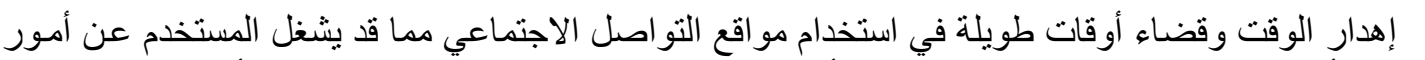

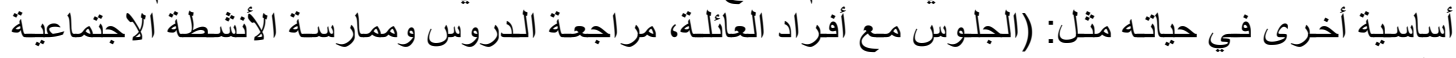
و المعيشية). • تغير السلوكيات واكتساب صفات غير حميدة من خلال التو اصل وربط العلاقات مع نساس مجهولين يتسمون

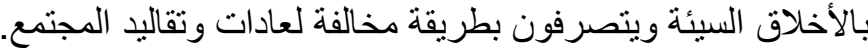

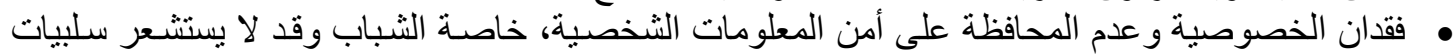

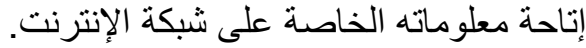

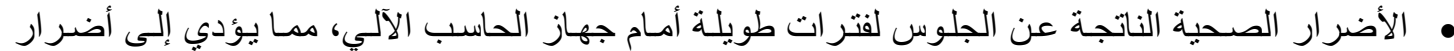

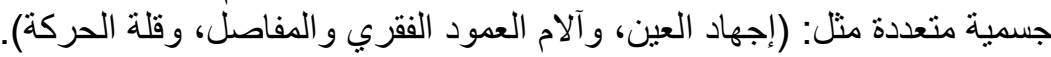

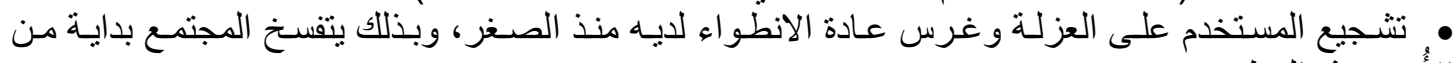

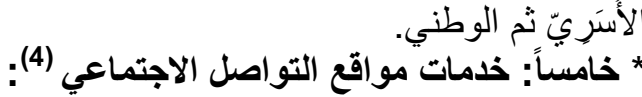

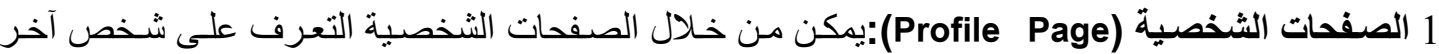

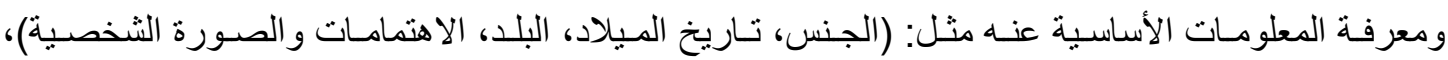
بالإضـافة إلى غير هـا من المعلومـات. ويعد الملف الثخصـي بوابـة الدخول لخصوصية الثـصه، فمن خـلال

( ) موقع ويكيبيديا، (سناب جات)، (http://ar.wikipedia.org/wiki)، تاريخ دخول الموقع (4-4-4) (2019).

$\left({ }^{2}\right)$ Flavin marketing. (Social Networking Exposed), 2009, pdf online, available at: <http:// markflavinblog.com/ reports/SocialNetworkingExposed.pdf>.access to the website on5-4-2019.

$\left({ }^{3}\right)$ Axel Bruns, Mark Bahnisch, (Social Media: Tools for User-Generated Content), 2009,pdf online, available at: <http://www.smartservicescrc.com.au/PDF/Social_Media_State_of_the \% 20Art_March 2009.pdf> .access to the website on5-4-2019.

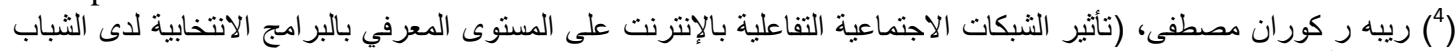

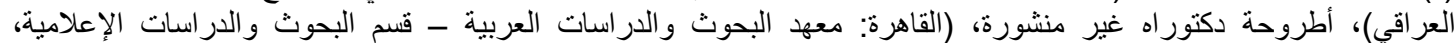

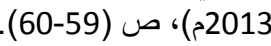




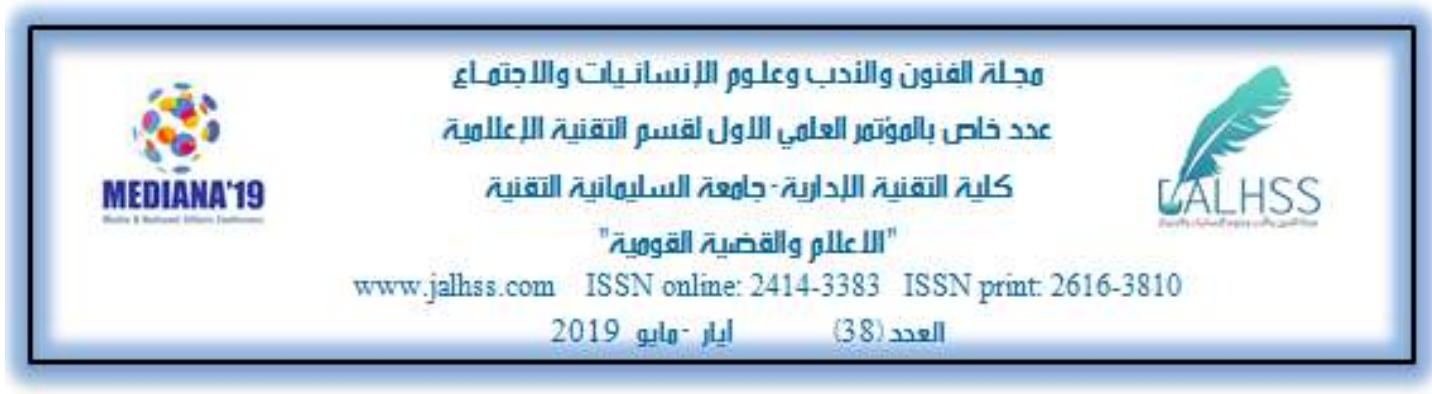

الصفحة الرئيسية للملف الثخصي يمكنك مشاهدة نشاط الثخص مؤخر اً، ومن هم أصدقاؤه، ومـا هي الصور الجديدة التي رفعها عن نفسه، إلى غير الرئ ذلك من النشاطاتت.

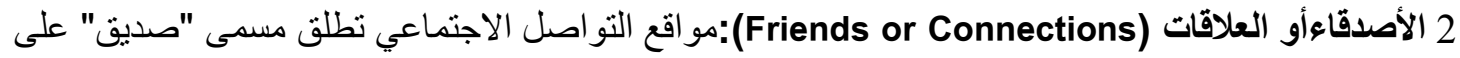

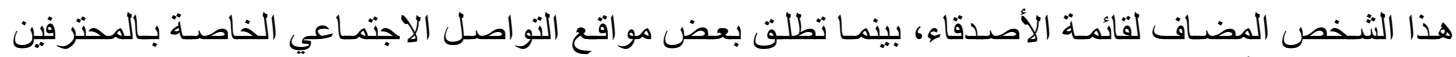

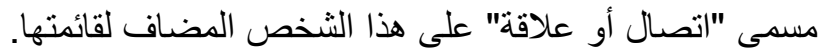

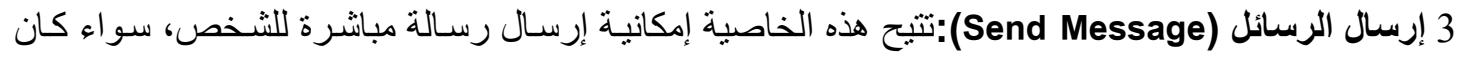
في قائمة الأصدقاء لديك أو لم يكن.

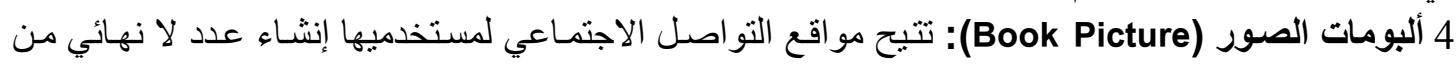

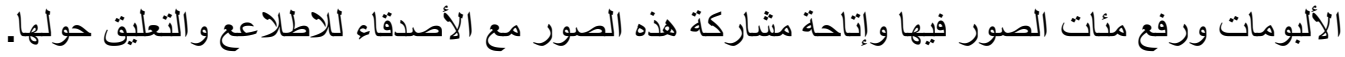

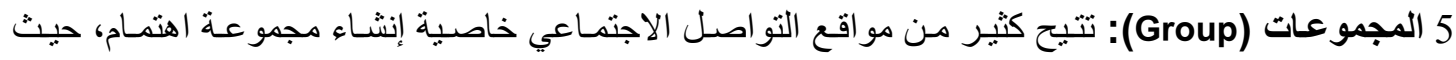

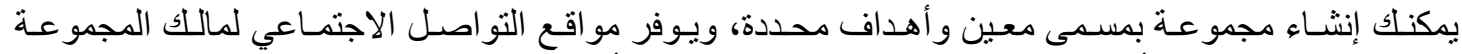

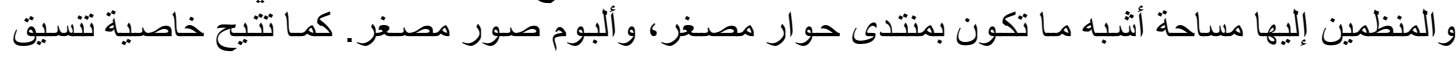

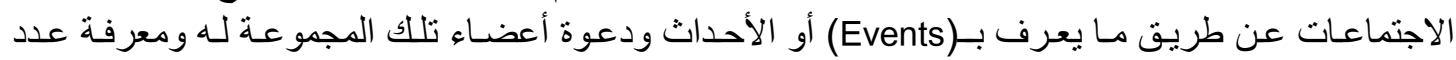
الحاضرين من عدد غير الحاضرين.

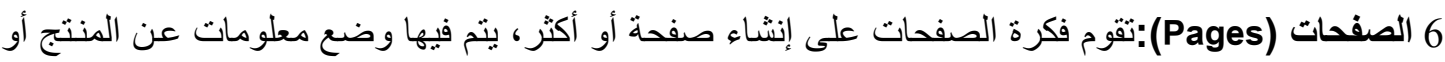

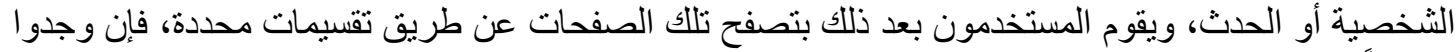

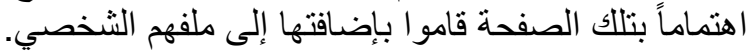

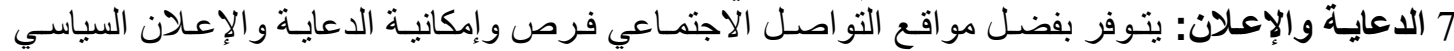

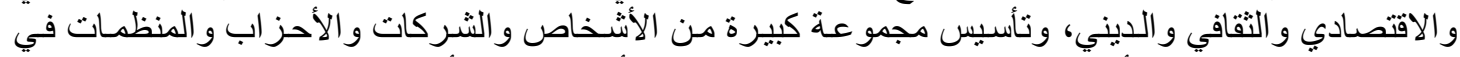

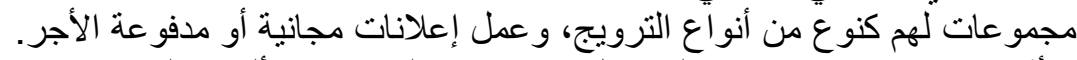

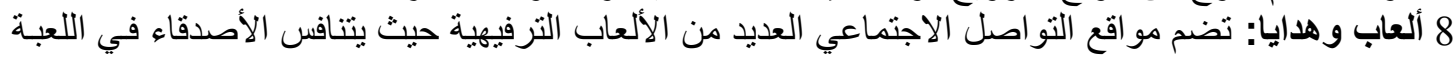

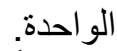

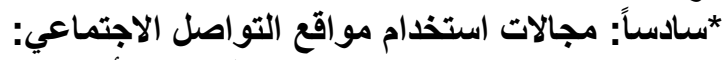

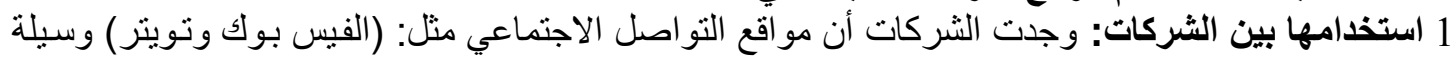

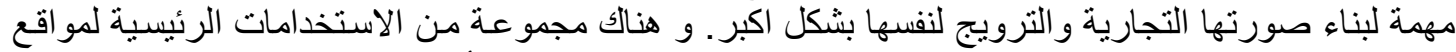

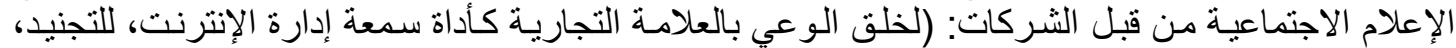

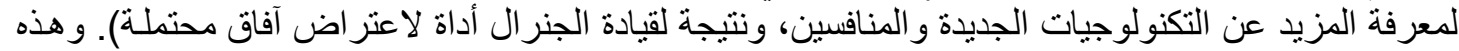

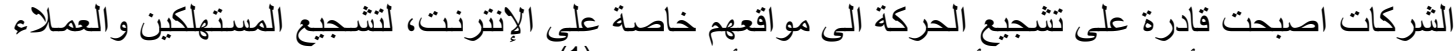

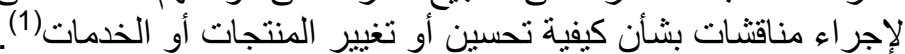

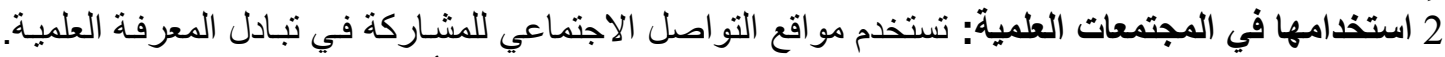

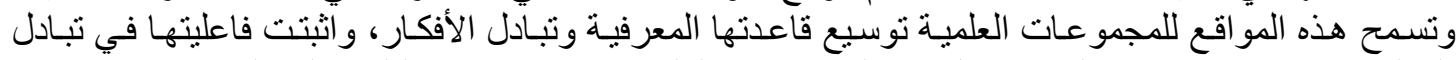
المعلومات بسر عة وكسر حالة الانعز ال بين المجمو عات العلمية واعت والاكاديمية في البلدان المختلفة.

( ${ }^{1}$ ) Arabie, Phipps, and Yoram Wind. (Marketing and Social networks), In Stanley Wasserman and Joseph Galaskiewicz, Advances in Social Network Analysis: Research in the Social and Behavioral Sciences. Thousand Oaks, Calif.: Sage Publications, 1994, pp. 254-273. Online <PDF>, available at: <http://books.google.com/books>, access to the website on 6-4-2019. 


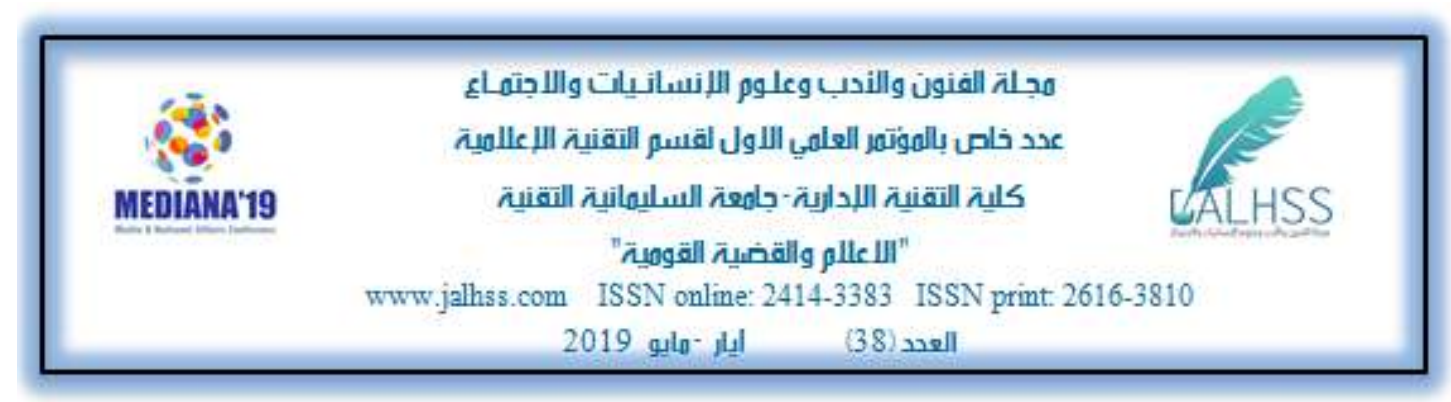

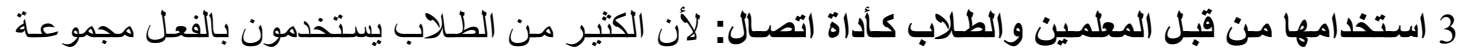

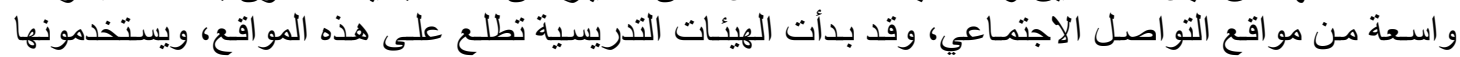

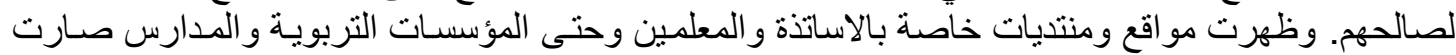

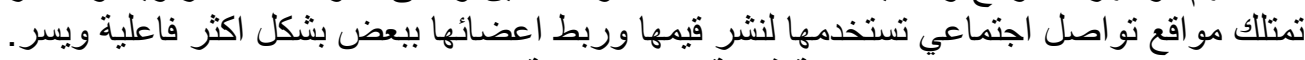

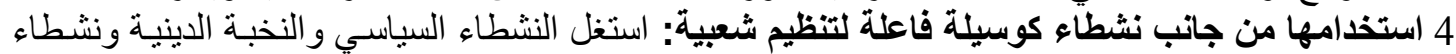

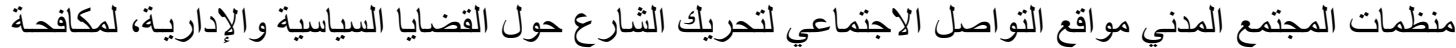

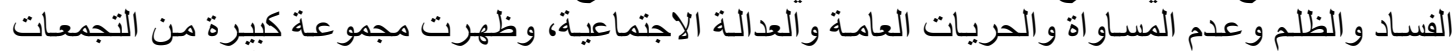

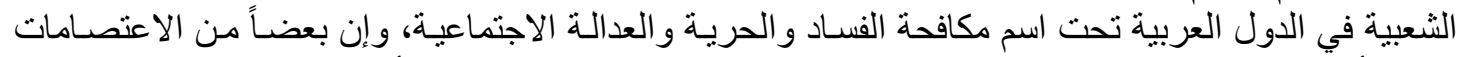

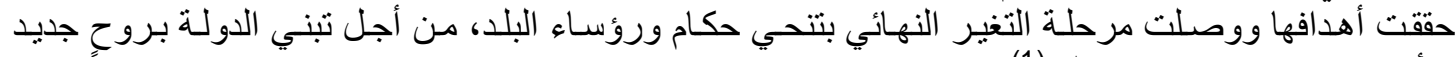

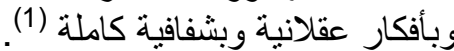

5 استخدامها من قبل المكتبات: يتم استخدامه للاتصال مع عدات عدد أكبر من المستخدمين المحتملين للمكتبة، فضلاً

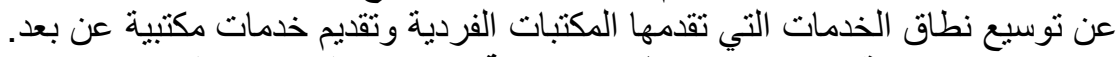

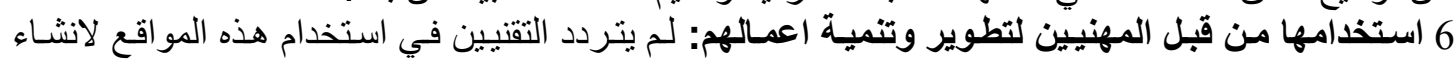

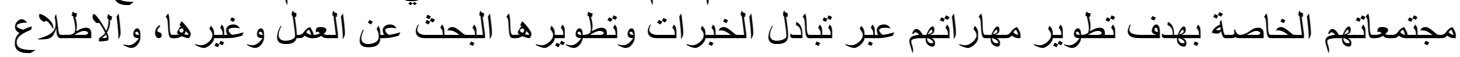
على المستجدات من الامور المتعقلة بمهنهم.

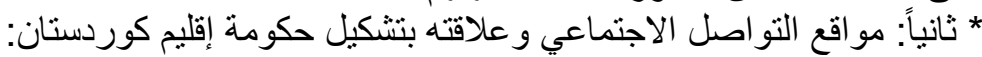

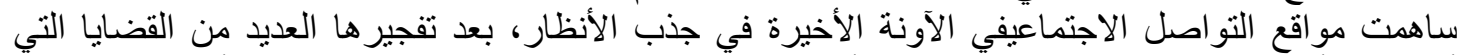

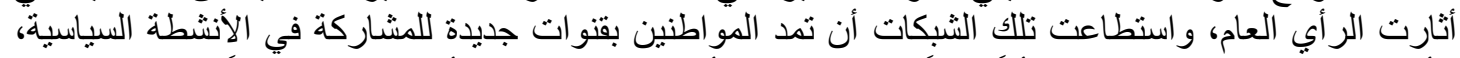

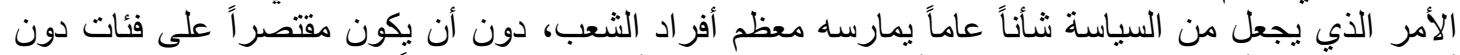
أخرى، وذّلك لأن هذه المواقع تشجع الأفراد غير الناشطين أو الفاعلين سياسياً على المشاركة في الفئ الفعاليات السياسية.

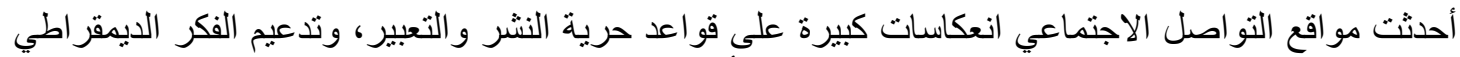

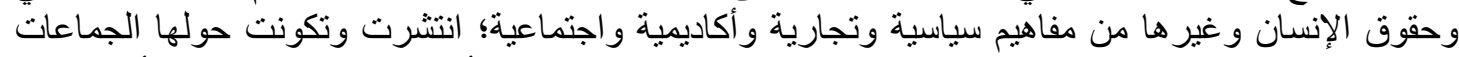

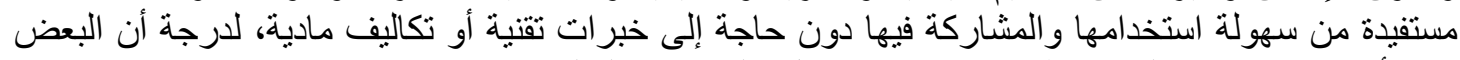

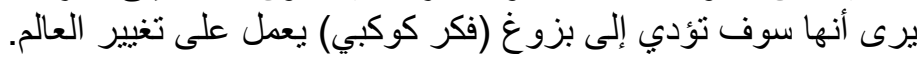

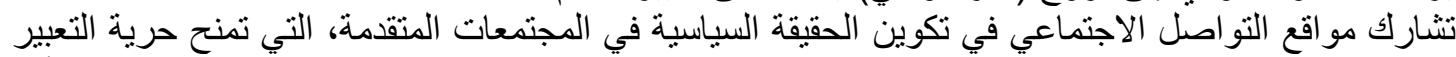

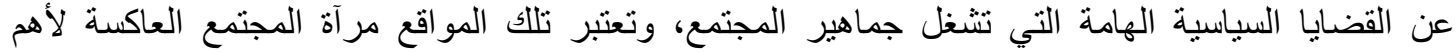

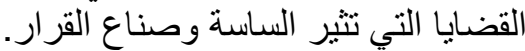

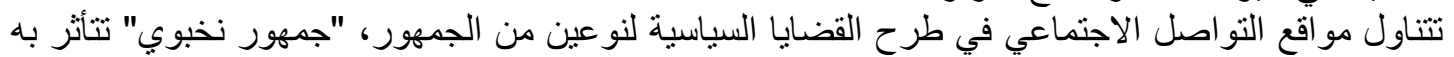

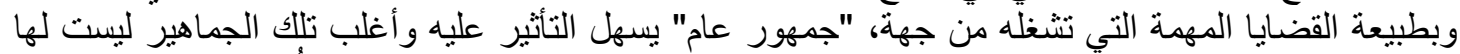

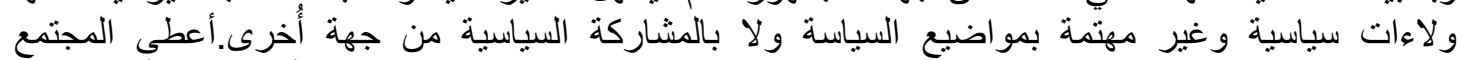

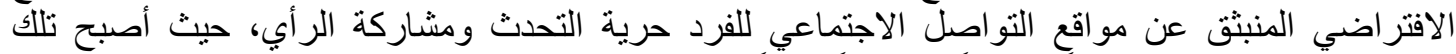

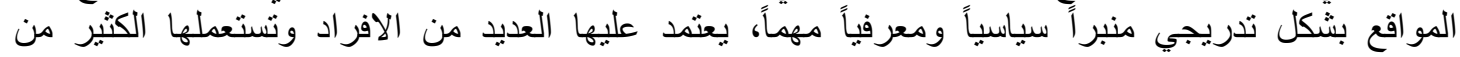
التوجهات التي تعنى بالتنغيير وحتمينها.

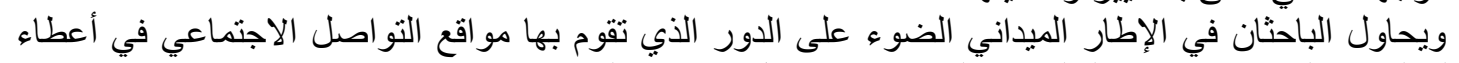
المعلومات لموظفي جامعة السليمانية التقنية نحو تشكيل حكومة إلقليم كوردستان.

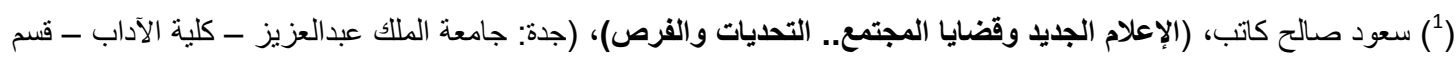

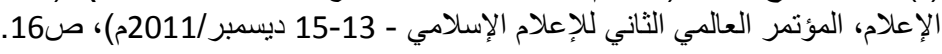


مجلة الفنون واللندب وعلوم اللإنسانيات واللاجِهـاع

عند خلم بالمونتمر العلميا الاول لقسم التقنية اللـاعلامية

كلية التقنية اللدازية -جامعت السليمانية التقنية

"

www.jalhss.com ISSN online: 2414-3383 ISSN print 2616-3810

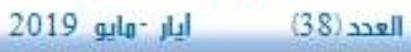

\section{المطلب الثالث: الإطار الميداني للبحث}

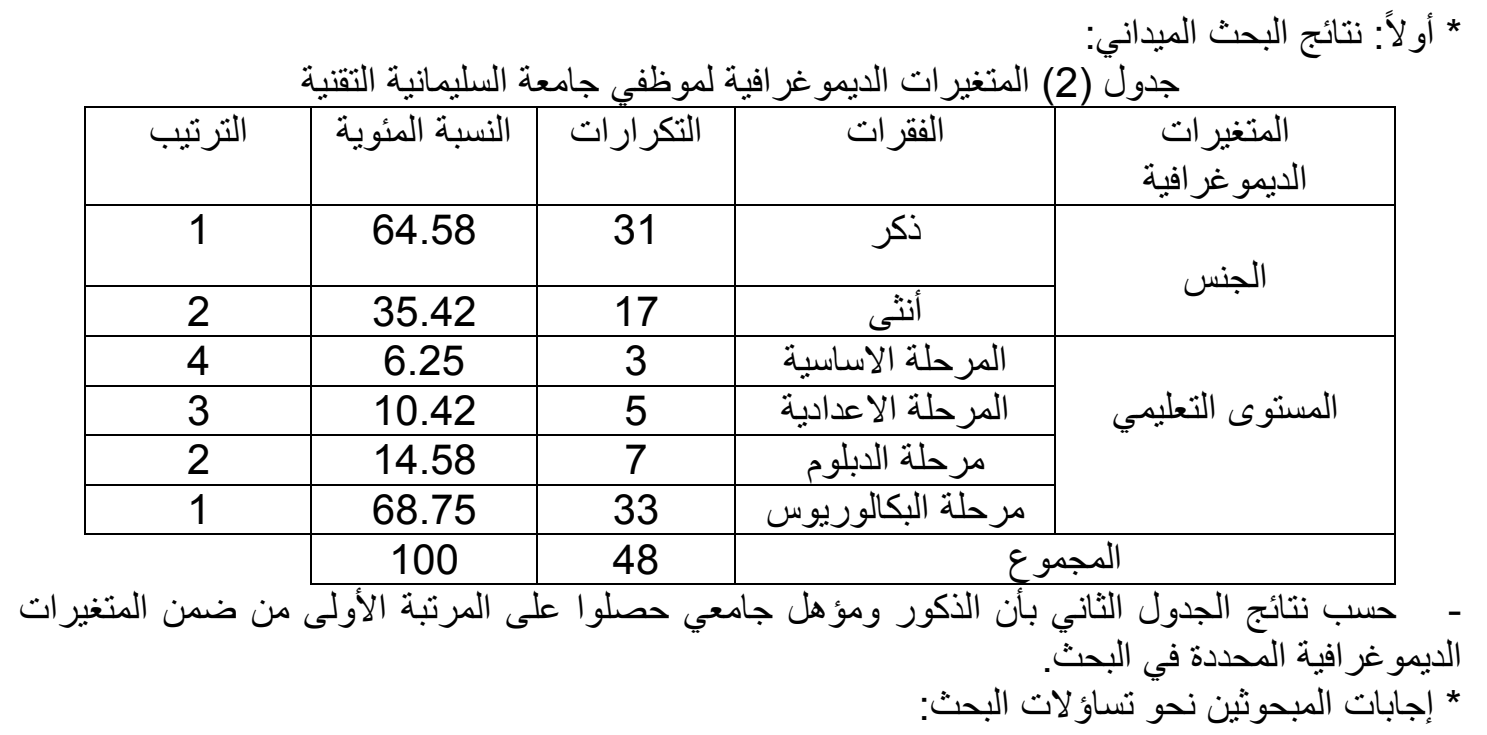

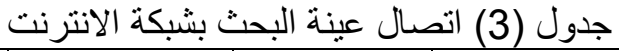

\begin{tabular}{|c|c|c|c|}
\hline الترتيب & النسبة المئوية & التكر ارات & العبار ات المطروحة للإجابة \\
\hline 1 & 97.92 & 47 & نعم \\
\hline 2 & 2.08 & 1 & $y$ \\
\hline & 100 & 48 & المجموع \\
\hline
\end{tabular}

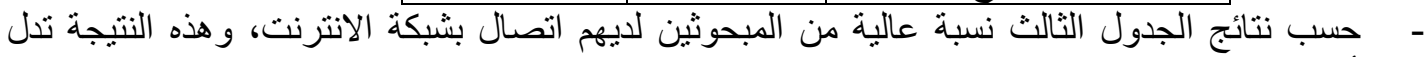

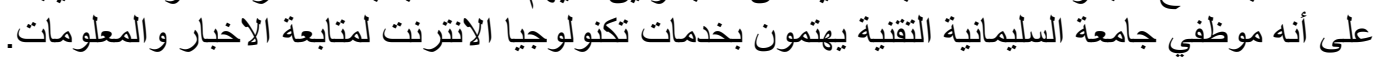

\begin{tabular}{|c|c|c|c|}
\hline الترتيب & النسبة المئوية & الت التكر ارات & العبار ات المطروحة للإجابة \\
\hline 4 & 4.17 & 2 & اقل من عام \\
\hline 3 & 27.08 & 13 & من عام الى ثلاثة اعو ام \\
\hline 2 & 31.25 & 15 & من ثلاثة الى خمسة اعوام \\
\hline \multirow[t]{2}{*}{1} & 37.5 & 18 & منذ خمسة اعو ام فاكثر \\
\hline & 100 & 48 & المجموع \\
\hline
\end{tabular}

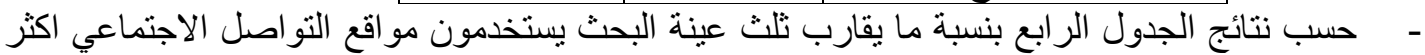

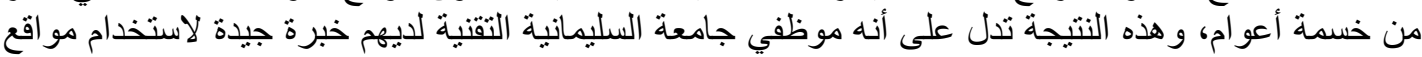
التو اصل الاجتماعي. 


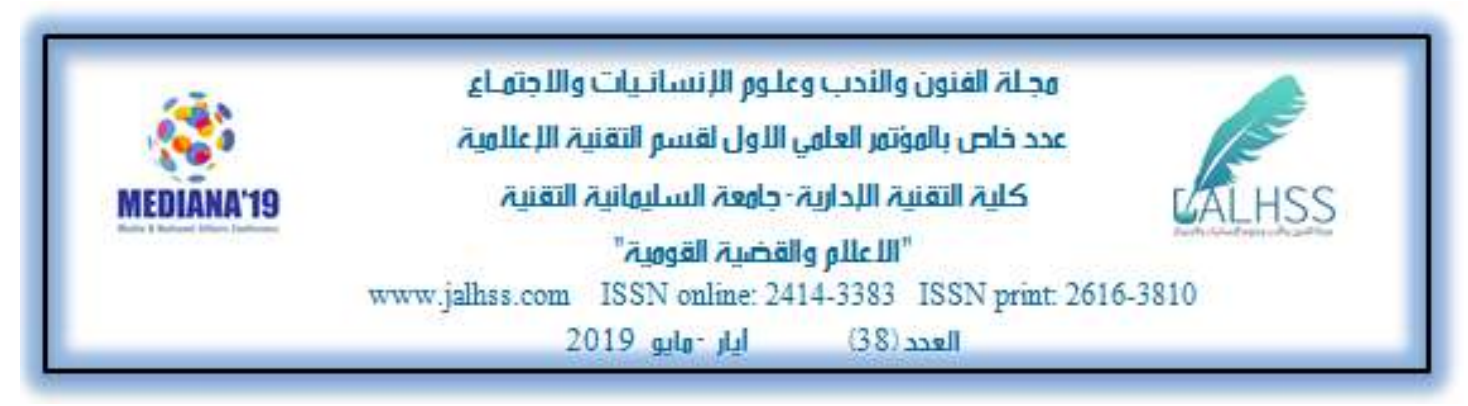

\begin{tabular}{|c|c|c|c|}
\hline الترتيب & النسبة المئوية & 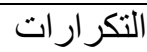 & العبار ات المطروحة للإجابة \\
\hline 1 & 56.25 & 27 & الهاتف الذكي \\
\hline 2 & 29.17 & 14 & الكمبيوتر \\
\hline \multirow[t]{2}{*}{3} & 14.58 & 7 & 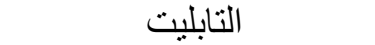 \\
\hline & 100 & 48 & المجموع \\
\hline
\end{tabular}

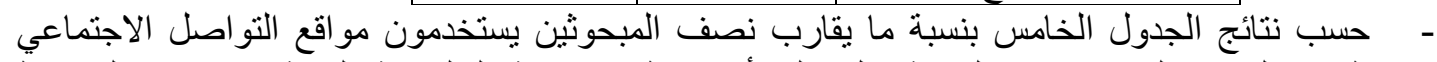

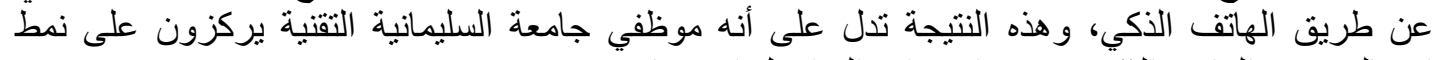
اتصالهم عبر الهاتف الذكي لاستخدام مواقع التو اصل على الاجتماعي.

جدول (6) مدى الاستخدام لمو اقع التو اصل الاجتماعي لدى المبحوثين

\begin{tabular}{|c|c|c|c|c|c|c|c|}
\hline \multirow{2}{*}{ الترتيب } & \multicolumn{2}{|c|}{ نادراً } & \multicolumn{2}{|c|}{ أحياناً } & \multicolumn{2}{|c|}{ دائماً } & \multirow{2}{*}{ مو اقع التو اصل الاجتماعي الاستخدام } \\
\hline & النسبة المئوية & التكر ارات & النسبة المئوية & التكر ارات & النسبة المئوية & التكر ارات & \\
\hline 1 & 2.08 & 1 & 6.25 & 3 & 91.67 & 44 & الفيس بوك \\
\hline 2 & 4.16 & 2 & 10.42 & 5 & 85.42 & 41 & اليوتيوب \\
\hline 3 & 10.42 & 5 & 14.58 & 7 & 75 & 36 & انستاغر ام \\
\hline 4 & 16.67 & 8 & 27.08 & 13 & 56.25 & 27 & سناب جات \\
\hline & 100 & 15 & 100 & 25 & 100 & 152 & المجموع" \\
\hline
\end{tabular}

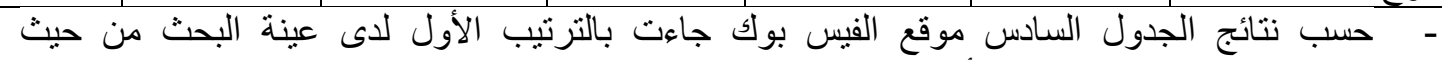

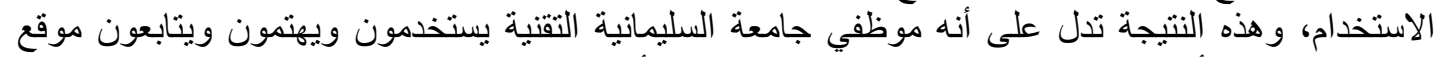
الفيس بوك بنسبة أعلى بمقارنة مو اقع التو اصلّ الاجتماعي الأخرى.

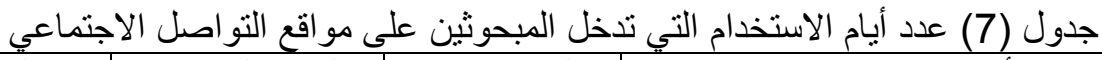

\begin{tabular}{|c|c|c|c|}
\hline الترتيب & النسبة المئوية & التكر ارات & عدد أيام الاستخدام \\
\hline 1 & 41.67 & 20 & يومياً \\
\hline 2 & 18.75 & 9 & يوم أو يومين في الأسبوع \\
\hline 3 & 12.5 & 6 & ثلاث أو أربع أيام في الأسبوع \\
\hline 4 & 10.42 & 5 & أربعة أبام \\
\hline 5 & 8.33 & 4 & خمسة أيام \\
\hline 6 & 4.17 & 2 & جميع ايام الأسبوع \\
\hline 7 & 4.17 & 2 & حسب الظروف \\
\hline & 100 & 48 & "المجموع" \\
\hline
\end{tabular}

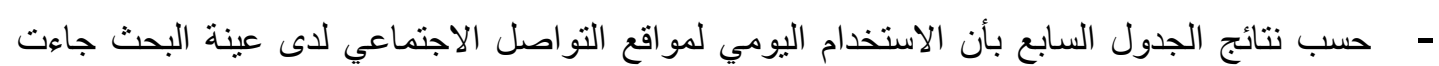

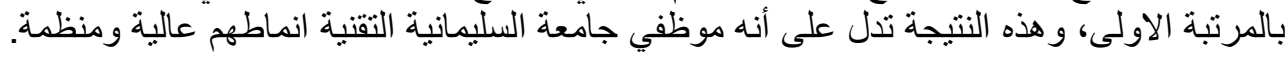




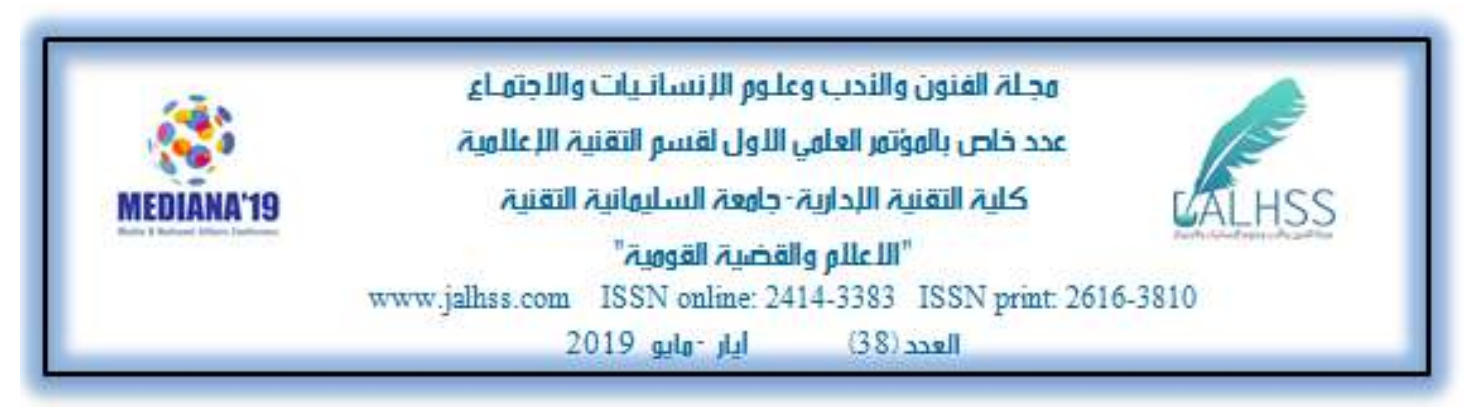

\begin{tabular}{|c|c|c|c|}
\hline الترتيب & النسبة المئوية & التكر ار ات & ساعات الاستخدام \\
\hline 3 & 8.33 & 4 & أقل من ساعة \\
\hline 4 & 6.25 & 3 & من ساعة لأقل من ساعتين \\
\hline 2 & 14.58 & 7 & من ساعتين لأقل من ثلاث ساعات \\
\hline 1 & 66.67 & 32 & ثناث ساعات فأكثر \\
\hline \multirow[t]{2}{*}{5} & 4.17 & 2 & حسب الظروف \\
\hline & 100 & 48 & المجموع \\
\hline
\end{tabular}

- حسب نتائج الجدول الثامن جاءت استخدام المبحوثين لمو اقع التواصل الاجتماعي أكثر من ثلاث ساعاعات

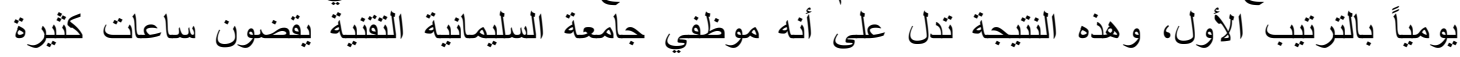
لاستخدام تلك المو اقع.

جدول (9) فترة استخدام مو اقع التو اصل الاجتماعي لدى عينة البحث

\begin{tabular}{|c|c|c|c|c|}
\hline الترنيب & النسبة المئوية & التكر ار ات & التوقيـــــــــ & الفتـــرة \\
\hline 6 & 2.08 & 1 & من 6.00 صباحاً إلى 10.00 صباحاً & الفترة الصباحية الفبة \\
\hline 4 & 6.25 & 3 & من 10.00 صباحاً إلى 1.00 ظهراً & فترة الضحى \\
\hline 5 & 4.17 & 2 & من 1.00 ظهر اً إلى 3.00 مساءاً & فترة الظهيرة \\
\hline 3 & 10.42 & 5 & من 3.00 مساءاً إلى 6.00 مساءاً & فترة العصر \\
\hline 2 & 16.67 & 8 & من 6.00 مساءاً إلى 10.00 مساءاً & فترة المساء \\
\hline 1 & 58.33 & 28 & من 10.00 مساءاً إلى 2.00 صباحاً & فترة السهرة \\
\hline \multirow[t]{2}{*}{7} & 2.08 & 1 & من 2.00 صباحاً إلى 6.00 صباح اليوم التالي & الفترة الممتدة \\
\hline & 100 & 48 & \multicolumn{2}{|l|}{ المجموع } \\
\hline
\end{tabular}

- حسب نتائج الجدول التاسع بأن أكثر من نصف البحوثين يستخدمون مواقع التواصل الاجتماعي في فترة

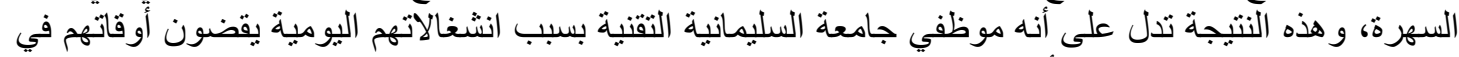
السهرة لكي ينو اصلو الويتابعوا أهم الاحداث و الاخهبار و واحتياجاتهم الثخصية.

جدول (10) عدد أصدقاء المبحوثين في مو اقع التو اصل الاجتماعي

\begin{tabular}{|c|c|c|c|}
\hline الترتيب & النسبة المئوية & التكر ارات & العبار ات المطروحة للإجابة \\
\hline 4 & 4.17 & 2 & اقل من مئة صديق \\
\hline 3 & 10.42 & 5 & من مئة الى اقل من 300 صديق \\
\hline 2 & 16.67 & 8 & من 300 الى اقل من 500 \\
\hline 1 & 68.75 & 33 & 500 صديق فاكثر \\
\hline & 100 & 48 & المجموع \\
\hline
\end{tabular}

- حسب نتائج الجدول العاثر بأن نسبة عالية من المبحوثين الذين يستخدمون مواقع التواصل الاجتماعي

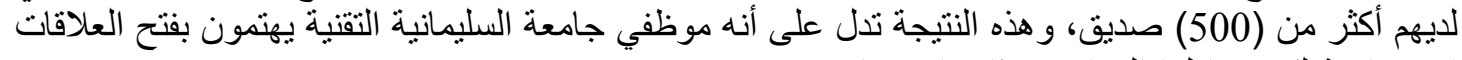

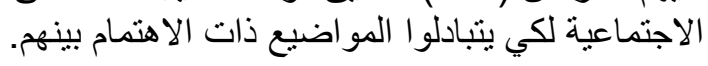




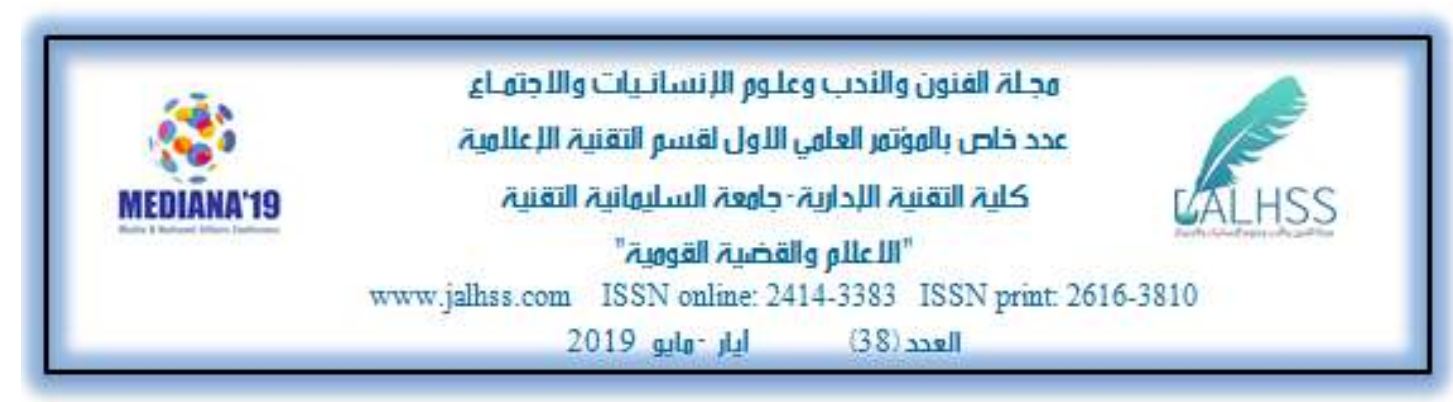

\begin{tabular}{|c|c|c|c|}
\hline الترتيب & النسبة المئوية & التكر ار ات & الموضو عات \\
\hline 1 & 37.5 & 18 & سياسية \\
\hline 2 & 18.75 & 9 & اقتصادية \\
\hline 7 & 2.08 & 1 & عسكرية \\
\hline 4 & 12.5 & 6 & اجتماعية \\
\hline 6 & 4.17 & 2 & متابعة احداث الجارية \\
\hline 8 & 2.08 & 1 & بئية \\
\hline 5 & 8.33 & 4 & دينية \\
\hline 3 & 14.58 & 7 & فنية \\
\hline & 100 & 48 & المجموع \\
\hline
\end{tabular}

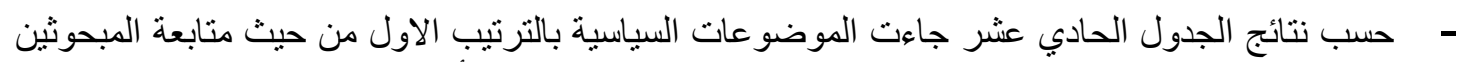

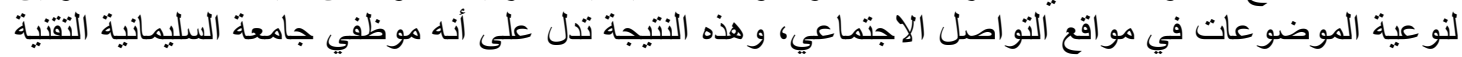
يهنمون ويتابعون القضايا السياسية الداخلية و الاقليمية والدولية الداعية.

\begin{tabular}{|c|c|c|c|}
\hline الترتيب & التنسبة المئوية & التكر ارات & العبار ات المطروحة للإجابة \\
\hline 1 & 43.75 & 21 & تشكيل حكومة اقليم كوردستان \\
\hline 2 & 18.75 & 9 & تشكيل برلمان اقليم كوردستان \\
\hline 5 & 8.33 & 4 & الصر اع السياسي بين الاحز اب السياسية \\
\hline 4 & 12.5 & 6 & اتفاقات بين الاحز اب السياسية \\
\hline \multirow[t]{2}{*}{3} & 16.67 & 8 & متابعة احداث الجارية وقضايا ساخنة \\
\hline & 100 & 48 & المجموع \\
\hline
\end{tabular}

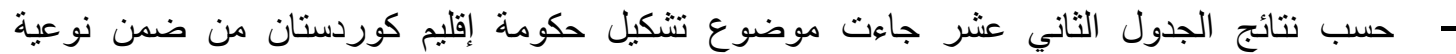

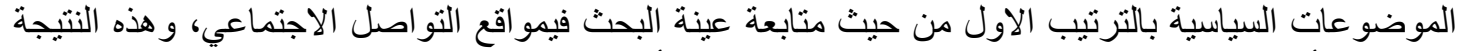

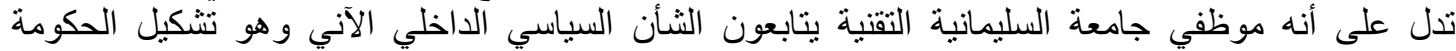

جدول (13) أثكال مشاركة عينة البحث في مو اقع التو اصل الاجتماعي إنهاعي

\begin{tabular}{|c|c|c|c|}
\hline الترتيب & النسبة المئوية & 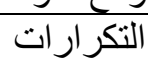 & العبار ات المطروحة للإجابة \\
\hline 1 & 68.75 & 33 & ارسال تعليقات على الحائط عن الموضو عات او القضايا المطروحة \\
\hline 2 & 31.25 & 17 & مناقتة معلومات سياسية مختلفة في رسالة على مو اقع التو اصل الاجتماعي \\
\hline & 100 & 48 & المجموع \\
\hline
\end{tabular}

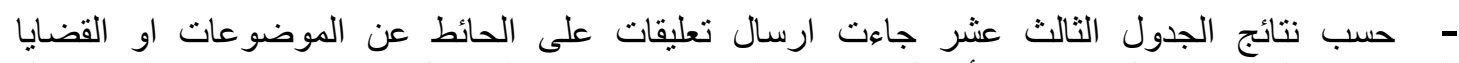
المطروحة بالترتيب الاول من حيث أثنكال مشاركة المبحوثين فيمو اقع التو اصل التئل الاجتماعي، و هذه النتيجة تدل

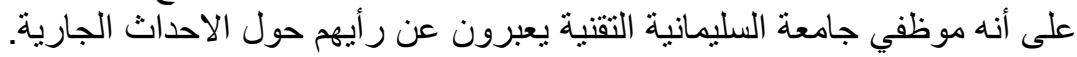




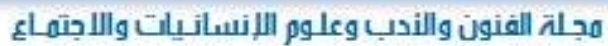

عدد خلم بالهوتمر العلمي اللاول لقسم التقنية اللاعلامية

كلية التقنية اللدازية -جامعت السليمانية التقنية

"

www.jalhss.com ISSN online: 2414-3383 ISSN print 2616-3810

2019 العدائ (38)

جدول (14) المناقتشة كوسيلة جيدة للمبحوثين في اعطاء المعلومات عن طريق مو اقع التو اصل الاجتماعي

\begin{tabular}{|c|c|c|c|}
\hline الترتيب & النسبة المئوية & التكر ار ات & العبار ات المطروحة للإجابة \\
\hline 1 & 70.84 & 34 & دائماً \\
\hline 2 & 20.83 & 10 & أحياناً \\
\hline 3 & 8.33 & 4 & نادراً \\
\hline & 100 & 48 & المجموع \\
\hline
\end{tabular}

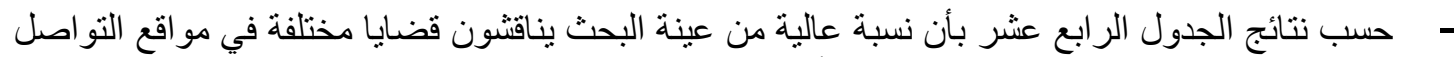

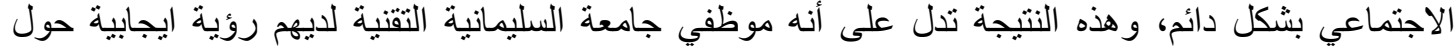

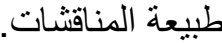

دول (15) مناقثة عينة البحث في مو اقع التو اصل الاجتماعي وتغيير موقفهم حول بعض القضايا

\begin{tabular}{|c|c|c|c|}
\hline 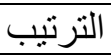 & النسبة المئوية & 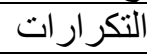 & العبار ات المطروحة للإجابة \\
\hline 1 & 77.08 & 37 & دائماً \\
\hline 2 & 16.67 & 8 & أحياناً \\
\hline \multirow[t]{2}{*}{3} & 6.25 & 3 & نادراً \\
\hline & 100 & 48 & المجموع \\
\hline
\end{tabular}

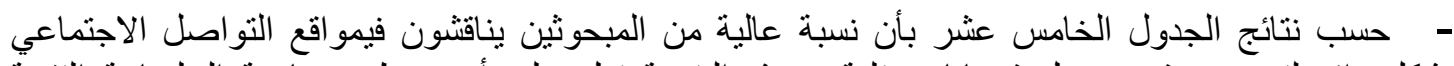

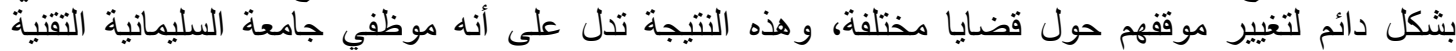
يؤثرون بتبادل المعلومات والحوار ات و والمناقتشات الجادة بينهم وبين مستخدمي آخرين.

جدول (16) إعطاء المعلومات الكافية نحو تثكيل حكومة إقليم كوردستان للمبحوثين عن طريق مو اقع التو اصل

\begin{tabular}{|c|c|c|c|}
\hline الترتيب & النسبة المئوية & التكر ار ات & العبار ات المطروحة للإجابة \\
\hline 1 & 72.92 & 35 & نعم \\
\hline 2 & 27.08 & 13 & $\gamma$ \\
\hline & 100 & 48 & المجموع \\
\hline
\end{tabular}

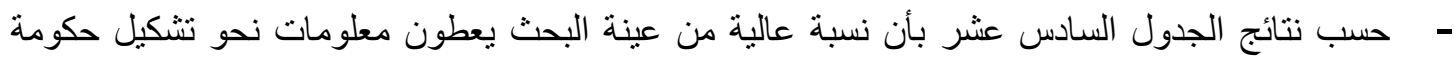

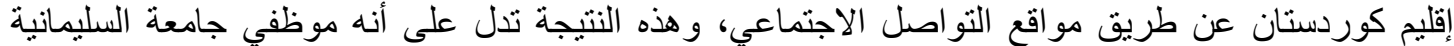

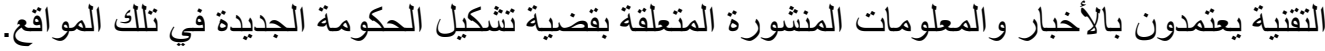

جدول (17) درجة ثقة عينة البحث بالمعلومات التي تحصل عليها في مواقع التواصل الاجتماعي نحو تشكيل حكومة اقليم كوردستان

\begin{tabular}{|c|c|c|c|}
\hline التزتيب & النسبة المئوية & التكر ارات & العبار ات المطروحة للإجابة \\
\hline 1 & 85.42 & 41 & نعم \\
\hline 2 & 14.58 & 7 & 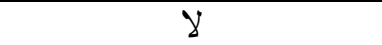 \\
\hline & 100 & 48 & المجموع \\
\hline
\end{tabular}




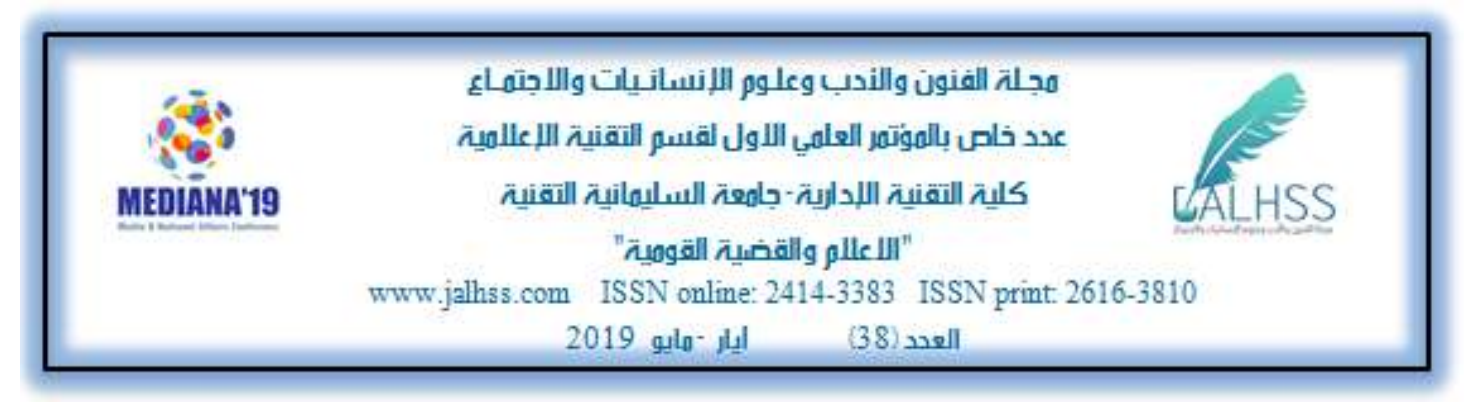

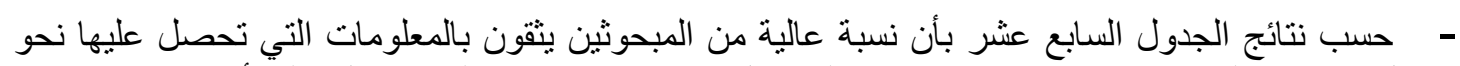

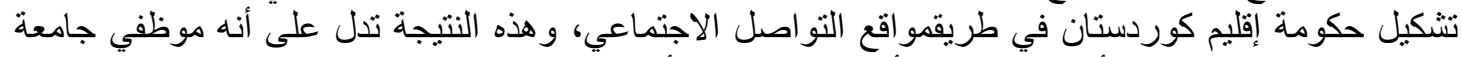

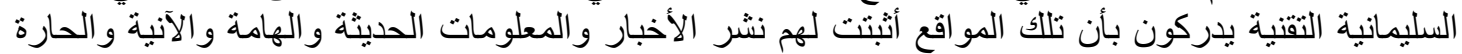
نحو تشكيل الحكومة الجديدة. جدول (18) أهم الموضو عات التي أثارتها مواقع التو اصل الاجتماعي للمبحوثين نحو تثكيل حكومة إقليم

\begin{tabular}{|c|c|c|c|}
\hline الترتيب & النسبة المئوية & التكر ارات & العبار ات المطروحة للإجابة \\
\hline 5 & 6.25 & 3 & تعزيز الروح الوطنية و الو لاء و الانتماء \\
\hline 2 & 16.67 & 8 & محاولة ربط الاحداث الجارية في الدول المجاورة بالوضع الداخلي \\
\hline 1 & 56.25 & 27 & الترويج لأر اءالسياسين والقادة نحو اجتماعات الأحز اب السياسية \\
\hline 3 & 12.5 & 6 & التشكيك في مصداقية ما تبثه مو اقع الاعلام الحزبية وغير الحزبية \\
\hline \multirow[t]{2}{*}{4} & 8.33 & 4 & اشاعة الفتن بين الاحز اب السياسية \\
\hline & 100 & 48 & المجموع \\
\hline
\end{tabular}

- حسب نتائج الجدول الثامن عشر جاءت الترويج لأر اء السياسين والقادة حول اجتماعات الأحزاب السياسية

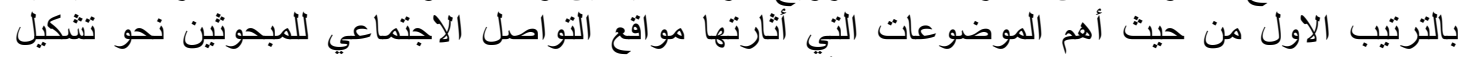

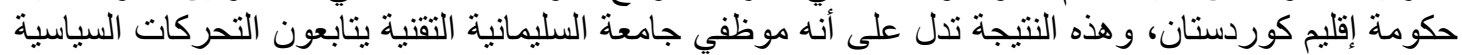
الداخلية بين الاحزاب السياسية للتفاوض حول طبيعة الحكومة الجديدة.

\begin{tabular}{|c|c|c|c|}
\hline الترتيب & النسبة المئوية & التكر ار ات & العبار ات المطروحة للإجابة \\
\hline 7 & 2.08 & 1 & لا اثق فيما تطرحه \\
\hline 3 & 14.58 & 7 & لا املك معلومات عنها \\
\hline 4 & 10.42 & 5 & وسيلة تخالف الأداب العامة \\
\hline 2 & 18.75 & 9 & تحرض على العنف \\
\hline 5 & 6.25 & 3 & لا تحقق رغباتي \\
\hline 6 & 4.17 & 2 & غير مفيدة ومملة \\
\hline \multirow[t]{2}{*}{1} & 43.75 & 21 & يسبب فوضى في المجتمع \\
\hline & 100 & 48 & المجموع \\
\hline
\end{tabular}

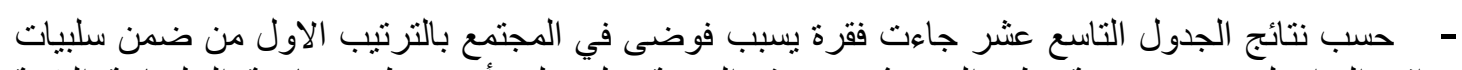

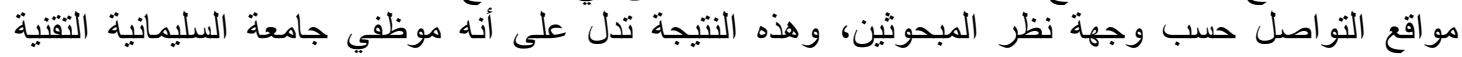

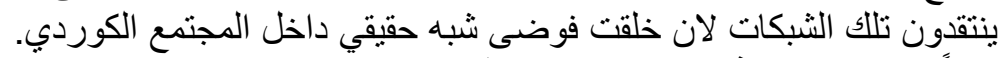
ثانياً: نتائج اختبار فروض البنان البحث ومناقشتئه:

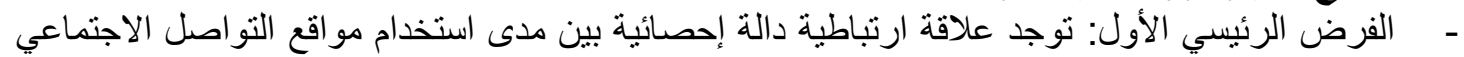

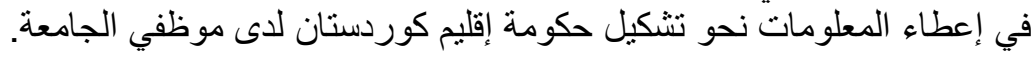




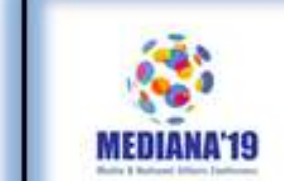

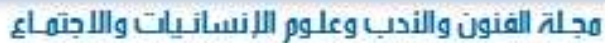 \\ عدد خلم بالهوتمر العلمي اللاول لقسم التقنية اللاعلامية \\ كلية التقنية اللدازية -جامعت السليمانية التقنية

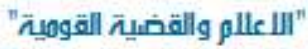

www.jalhss.com ISSN online: 2414-3383 ISSN print: 2616-3810

2019 العدي

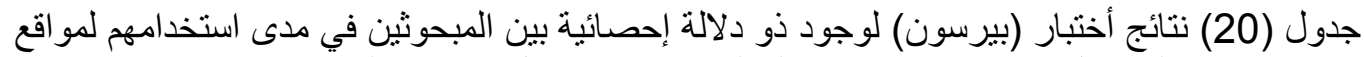

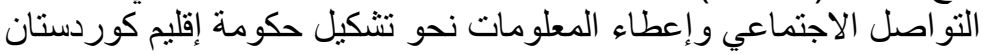

\begin{tabular}{|c|c|c|c|c|c|}
\hline مستوى الدلالة & المعنوية & بيرسون & المعياري & الحسابي & إعطلاء المعلومات \\
\hline دالة & 0.000 & 0.864 & 1.59 & 2.86 & \\
\hline
\end{tabular}

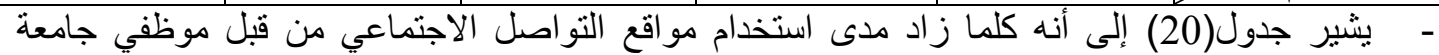

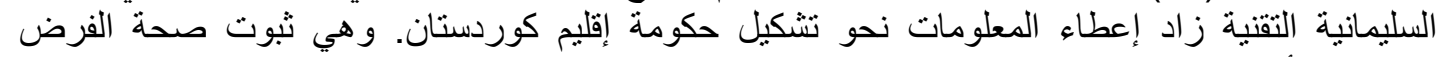

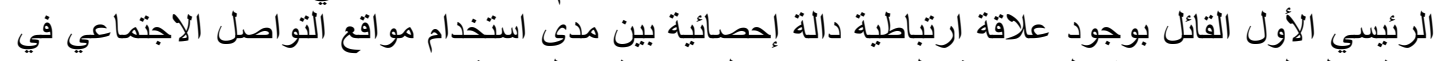
إعطاء المعلومات نحو تشكيل حكومة إقليم كوردستان لدى موظفي الجامعة.

- الفرض الرئيسي الثاني: نوجد فروق ذو دلالة إحصائية بين المبحوثين في إعطاء المعلومات نحو تثكيل حكومة إقليم كوردستان حسب الرئين توحير فروات الديمو غر دافية.

جدول (21) نتائج أختبار (z) لفروق ذو دلالة إحصائية بين المبحوثين في إعطاء المعلومات نحو تشكيل

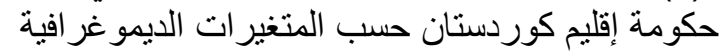

\begin{tabular}{|c|c|c|c|c|c|c|c|}
\hline مستوى الدلالة & الانحراف & الحسابي & إختبار (Z) & مجموع & متوسط الرتب & التكر ارات & / إعطاء المعلومات \\
\hline 0.000 & 10.73 & 24.09 & - 7.028 & 1125.00 & 23.75 & 48 & \\
\hline
\end{tabular}

- يشير جدول(20) إلى ثبوت صحة|الفرض الرئيسي الثاني بوجودفروق ذو دلالة إحصـائية بين المبحوثين

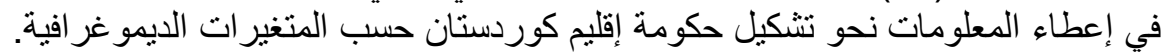
* * استتناجات وتوصيات ومقترحات البحث:

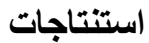

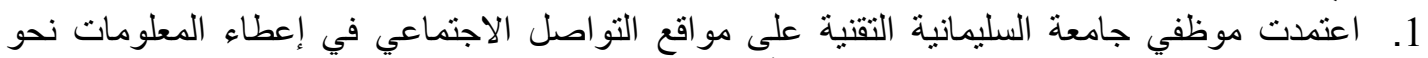

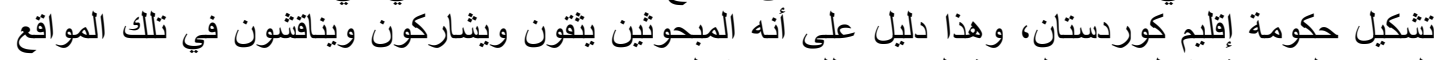

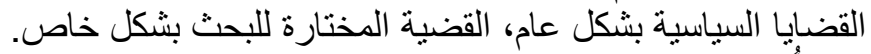

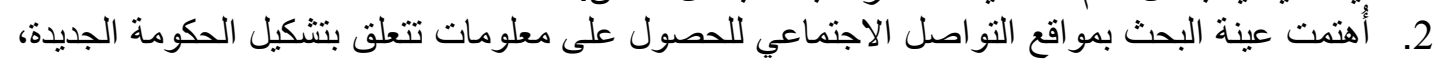
ولكن بإختلاف خصائهم الديمو غر افية. التوصيات

1. يوصي الباحث الاحزاب السياسية بمعرفة طبيعة استخدام مواقع التواصل الاجتماعي لكي تعطي

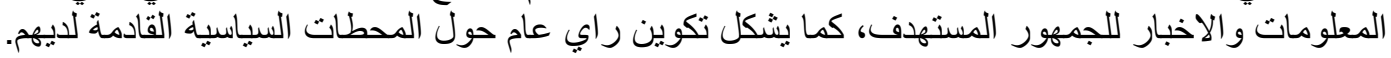

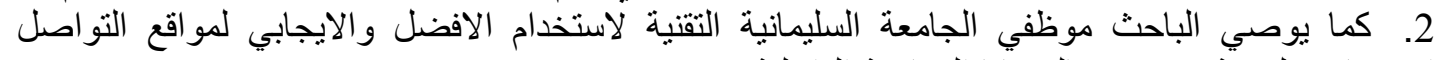
الاجتماعي لتقوية معرفتهم بالقضايا السياسية الداخلية.

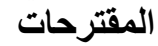

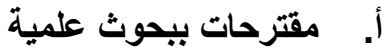

1 2 
مجلم الفنون والندب وعاوم اللإنسانيات واللاجتهماع

عدد خام بالهونتمر العلمي اللاول لقسم التقنية اللاعلامية

MEDIĀMA'19

كلية التقنية اللدازية -جاهعت السليمانية التقنية

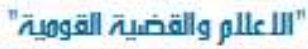

www.jalhss.com ISSN online: 2414-3383 ISSN print: 2616-3810

2019 العدايل

ب. مقترحات ببحوث تطبيقية

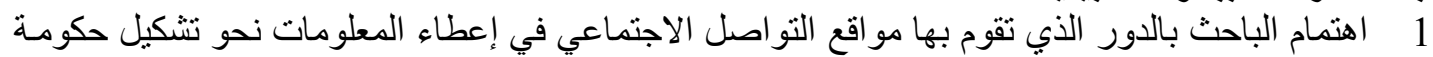
إقليم كوردستان لدى موظفي جامعة السليمانية التقنية.

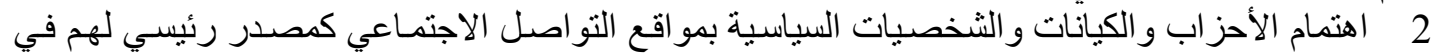

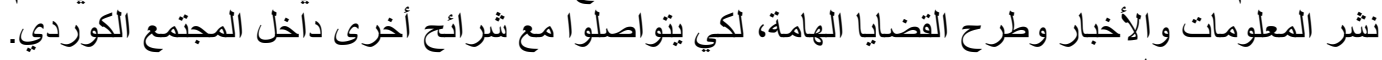

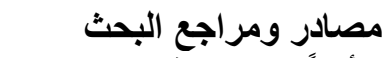

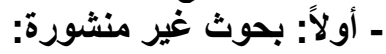

1. 17. ريبه ر كوران مصطفى، (تأثثر الثبكات الاجتماعية التفاعلية بالإنترنت على المستوى المعرفي

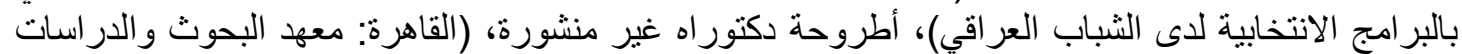

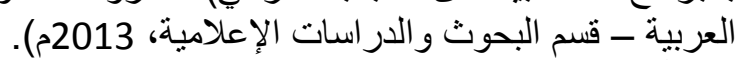
ـ ثانياً: بحوث منشورة: 1. سعود صالح كاتب، (الإعلام الجديد وقضايا المجتمع.. التحديات و الفرص)، (جدة: جامعة الملك عبدالعزيز

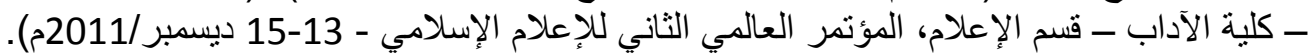

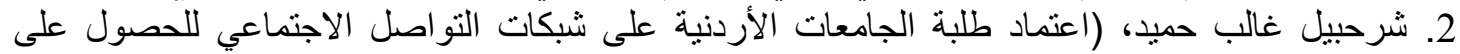

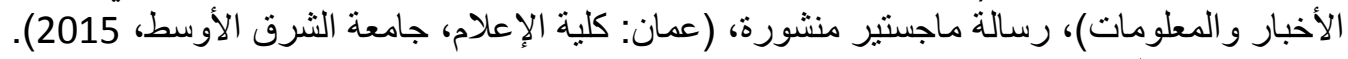
3. ماطر عبداله حمدي، (اعتماد الثباب الجامعي على مواقع التواصل الهل الاجتماعي في التزود بالمعلومات:

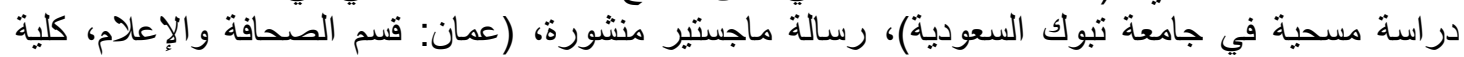
الإعلام، جامعة الثرق الأوسط، مأدة 2018).

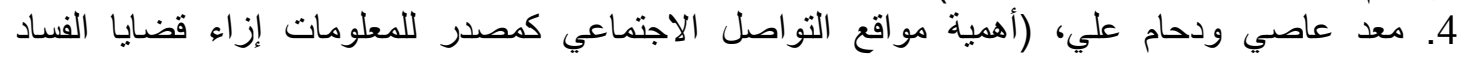
السياسي)، بحث منشور، (ديالى: مجلة كلية القانون للعلوم القانونية والسياسية، كلية القانون، جامعة ديالى،

(2016

5. Arabie, Phipps, and Yoram Wind. (Marketing and Social networks), In Stanley Wasserman and Joseph Galaskiewicz, Advances in Social Network Analysis: Research in the Social and Behavioral Sciences. Thousand Oaks, Calif.: Sage Publications, 1994, pp. 254-273. Online <PDF>, available at: <http://books.google.com/books>, access to the website on 6-4-2019.

6. Axel Bruns, Mark Bahnisch, (Social Media: Tools for User-Generated Content), 2009,pdf online, available at: <http://www.smartservicescrc. com.au/PDF/Social_Media_State_of_the $\%$ 20Art_March 2009.pdf> .access to the website on5-4-2019.

7. Cindy Royal. (User-Generated Content: How Social Networking Translates to Social Capital), 2008, Association for Education in Journalism and Mass Communication Annual Convention, online, adf avalable at:<http://www.allacademic.com/meta/p271193_index.html> access to the website on2-42019.

8.Flavin marketing. (Social Networking Exposed), 2009, pdf online, available at: <http:// markflavinblog.com/ reports/SocialNetworking Exposed.pdf>.access to the website on5-42019.

9. Hitwise and Experian. (Social Networking), 2007, [Online]. Available at: <http://www.Bergenmediaby.no/admin/ressurser/QCetFnO\$_11_Social_Networking_Report_ 2008.pdf $>$.access to the website on 1-4-2019. 


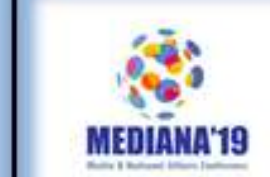

\section{هجلاة الفنون والندب وعلوم اللإنسانيات واللاجتهـاع \\ عدد خام بالهوتمر العلهي اللاول لقسم التقنية اللـاعلامية كلية التقنية اللدازية -جاهعت السليمانية التقنية} "

www.jalhss.com ISSN online: 2414-3383 ISSN print 2616-3810 2019 العدائ (38)

1. الكتب: احمد جرار، (الفيس بوك والثباب العربي)، (عمان: مكتبة الفلاح للنشر والتوزيع، الطبعة الأولى، (2012

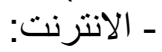

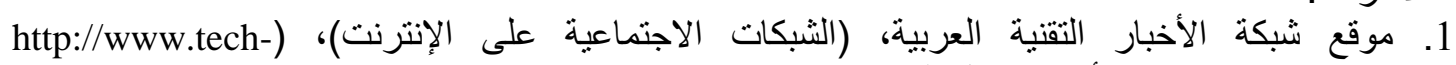
(arabia.com/?p= 663 ، تأريخ دخول الموقع: (19-4-4) (2019). 2. www.en.org/ (Cyworld), access to the website on2-4-2019.

3. www. (Social_networking_service).Org. access to the website on2-4-2019.

4. Facebook. html online, available at: <http://en.org/wiki/Facebook>. access to the website on3-4-2019.

5. Twitter.about us. html online, available at: <http://twitter.com/about>. access to the website on3-4-2019.

6. موقع ويكيبيديا، (يوتيوب)، (http://ar.wikipedia.org/wiki)، تاريخ دخول الموقع (4-4/2019-4).

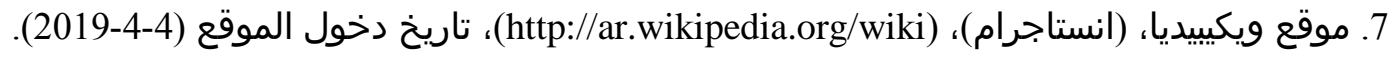

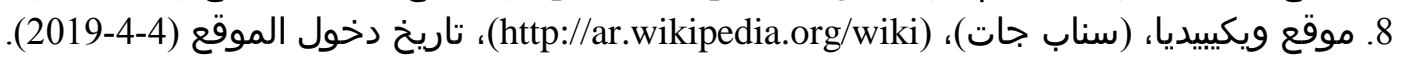

